\title{
Effects of Elevated pCO2 and Irradiance on Growth, Photosynthesis and Calcification in Halimeda discoidea
}

\author{
K.E. Peach
}

Florida Atlantic University

M. S. Koch

Florida Atlantic University

Patricia Blackwelder

University of Miami; Nova Southeastern University, pblackwe@nova.edu

Find out more information about Nova Southeastern University and the Halmos College of Natural Sciences and Oceanography.

Follow this and additional works at: https://nsuworks.nova.edu/occ_facarticles

Part of the Marine Biology Commons, and the Oceanography and Atmospheric Sciences and Meteorology Commons

\section{NSUWorks Citation}

K. E. Peach, M. S. Koch, and Patricia Blackwelder. 2016. Effects of Elevated pCO2 and Irradiance on Growth, Photosynthesis and Calcification in Halimeda discoidea .Marine Ecology Progress Series : 143 -158. https://nsuworks.nova.edu/occ_facarticles/764.

This Article is brought to you for free and open access by the Department of Marine and Environmental Sciences at NSUWorks. It has been accepted for inclusion in Marine \& Environmental Sciences Faculty Articles by an authorized administrator of NSUWorks. For more information, please contact nsuworks@nova.edu. 


\title{
Effects of elevated $p \mathrm{CO}_{2}$ and irradiance on growth, photosynthesis and calcification in Halimeda discoidea
}

\author{
K. E. Peach ${ }^{1, *}$, M. S. Koch ${ }^{1}$, P. L. Blackwelder ${ }^{2}$ \\ ${ }^{1}$ Florida Atlantic University, Department of Biological Sciences, 777 Glades Road, Boca Raton, FL 33431, USA \\ ${ }^{2}$ Nova Southeastern University, 8000 North Ocean Drive, Dania Beach, FL 33004 and University of Miami, \\ Center for Advanced Microscopy, 1252 Memorial Drive, Coral Gables, FL 33146, USA
}

\begin{abstract}
Ocean acidification (OA) effects on photophysiology and calcification were examined in Halimeda discoidea, a calcifying macroalga that produces tropical reef sediments. Photosynthetic parameters, including maximum photosynthetic rate $\left(P_{\max }\right)$, photosynthetic efficiency $(\alpha)$ and compensating irradiance $\left(I_{c}\right)$ were determined in short-term assays on live thalli after a $10 \mathrm{~d}$ exposure to 4 levels of $\mathrm{CO}_{2}$ partial pressures $\left(\mathrm{CCO}_{2} ; 491,653,982\right.$ and $\left.1201 \mu \mathrm{atm}\right)$ under saturating (300 $\mu \mathrm{mol}$ photons $\left.\mathrm{m}^{-2} \mathrm{~s}^{-1}\right)$ and sub-saturating $\left(90 \mu \mathrm{mol}\right.$ photons $\left.\mathrm{m}^{-2} \mathrm{~s}^{-1}\right)$ irradiance in an aquaria study. Morphology of aragonite crystals produced in segments formed on adult thalli was characterized using scanning electron microscopy (SEM). Further, we examined crystal morphology and changes in inorganic content of non-living segments exposed to elevated (1201 $\mu \mathrm{atm})$ and ambient $p \mathrm{CO}_{2}$ for $27 \mathrm{~d}$ to assess OA effects on carbonate sediments generated from $H$. discoidea. Even though $P_{\max }$ was higher under elevated $p \mathrm{CO}_{2}$, this photophysiological response did not result in higher calcification rates. Based on crystal measurements and SEM imagery, aragonite crystals within new segments were indistinguishable across $p \mathrm{CO}_{2}$ and irradiance treatments. Under high irradiance, new segments showed a greater investment in organic versus inorganic production. Non-living segments contained narrower crystals after $27 \mathrm{~d}$ exposure to elevated $p \mathrm{CO}_{2}$ relative to controls, but differences were small $(0.03 \mu \mathrm{m})$ and did not contribute significantly to changes in normalized biomass or inorganic content. Based on these results, $H$. discoidea will likely produce new calcified segments with intact aragonite crystals under year $2100 p \mathrm{CO}_{2}$ levels at high and low irradiance, while aragonite crystals of the sediment may produce thinner needle carbonate muds.
\end{abstract}

KEY WORDS: Photosynthesis $\cdot$ Calcification $\cdot$ Dissolution $\cdot \mathrm{CO}_{2} \cdot$ Ocean acidification $\cdot$ Irradiance $\cdot$ Halimeda

\section{INTRODUCTION}

Macroalgae of the genus Halimeda are important contributors to carbonate sediments and reef building in the tropics (Goreau 1963, Stoddart 1969, Milliman 1974, Wiman \& McKendree 1975, Hillis-Colinvaux 1980, Alexandersson \& Milliman 1981, Jensen et al. 1985, Rees et al. 2007, Kangwe et al. 2012). This genus accounts for $8 \%$ of the global carbonate budget (Hillis 1997) and constitutes up to $40 \%$ of reef sediments through calcification and a high turnover rate of segments comprised of calcium carbonate
$\left(\mathrm{CaCO}_{3}\right)$ crystals, principally aragonite (Hillis-Colinvaux 1980). While Halimeda currently has a broad distribution, growing under a range of environmental conditions, the effects of ocean acidification (OA) on its physiology, growth and calcification rates are only now being elucidated (Ries et al. 2009, Robbins et al. 2009, Price et al. 2011, Sinutok et al. 2011, 2012, Comeau et al. 2013b, Campbell et al. 2014, Hofmann et al. 2014, Johnson et al. 2014, Vogel et al. 2015a,b, Wizemann et al. 2015b).

Halimeda thalli grow by adding new segments that are produced through the extension of filaments. Fil- 
aments expand and fuse together at their terminus, also termed 'primary utricles', defining the perimeter of a newly forming segment which expands over time (Borowitzka \& Larkum 1977). Production of these primary utricles creates interutricular spaces (IUS) or extracellular cavities between the terminal filaments. This IUS becomes semi-isolated from the external seawater as the segment grows, thereby making the space more conducive for calcification (Wilbur et al. 1969, Borowitzka \& Larkum 1976a, 1976b, 1977). In addition to purely physical isolation of the IUS, external carbonic anhydrase and active ion transport systems, as well as photosynthesis within the utricle, are thought to promote calcification by removing $\mathrm{CO}_{2}$ and increasing IUS pH (Borowitzka \& Larkum 1976b, 1977, Borowitzka 1989, de Beer \& Larkum 2001, Wizemann et al. 2014). Aragonite crystal formation in the IUS is considered a two-stage process, primary crystal formation followed by secondary crystal development (Borowitzka \& Larkum 1977, 1987, Macintyre \& Reid 1995, Comeau et al. 2013a, Wizemann et al. 2014). Primary crystal formation in Halimeda is thought to be under biological control that is initiated within an organic matrix on the outer utricle wall where external carbonic anhydrase catalyzes the conversion of $\mathrm{CO}_{2}$ into $\mathrm{HCO}_{3}{ }^{-}$, a possible substrate for $\mathrm{CaCO}_{3}$ formation. Secondary crystals are postulated to precipitate abiotically via photosynthesis with primary crystals serving as seeds for new nucleation. Primary aragonite crystals at the utricle-IUS boundary also form small $(<1 \mu \mathrm{m})$ micro-anhedral carbonates considered to be primary crystals that have undergone dissolution and recrystallization in response to nighttime respiration (Macintyre \& Reid 1995, Wizemann et al. 2014). This mechanism was put forth to explain the lack of intact aragonite needles $(<20 \%)$ in carbonate sediments (Macintyre \& Reid 1995). Based on this model, the micro-anhedral carbonates move into the interior of the IUS over time, solidifying the carbonate crystals and leading to 'primary cementation'; this cementation appears to occur in some, but not all, Halimeda species. Because of the link between micro-anhedral carbonate formation and $\mathrm{CO}_{2}$ production through respiration and associated dissolution, micro-anhedral carbonates may increase under elevated partial pressure of $\mathrm{CO}_{2}$ $\left(p \mathrm{CO}_{2}\right)$ with OA.

Aragonite crystal structure in Halimeda has been shown to be altered under elevated $p \mathrm{CO}_{2}$ and lower pH (Robbins et al. 2009, Sinutok et al. 2011, Wizemann et al. 2015b). A drop in the IUS saturation state of aragonite $\left(\Omega_{\mathrm{Ar}}\right)$ below threshold levels for calcification $(\sim 1)$ can lead to the loss of previously calcified aragonite crystals (Sinutok et al. 2011). Robbins et al. (2009) found that crystals in more recent samples (2000's) of 2 Halimeda species (H. discoidea and $H$. incrassata) had smaller widths and were more abundant than crystals formed $\sim 40$ yr prior. Robbins et al. (2009) proposed that these crystal changes were in response to lower coastal ocean $\mathrm{pH}$ over time from an increase in ecosystem respiration rates (elevated $p \mathrm{CO}_{2}$ ) under coastal nutrient enrichment. They also found higher densities of smaller crystals in $H$. opuntia and $H$. tuna new segments formed in $\mathrm{CO}_{2}$ enriched seawater $(\sim 1700 \mu \mathrm{atm})$ after $21 \mathrm{~d}$. Similar increases in abundance of more slender aragonite crystals of $H$. opuntia were observed by Wizemann et al. (2015b) after $45 \mathrm{~d}$ in elevated $p \mathrm{CO}_{2}(\sim 650 \mu \mathrm{atm})$ seawater treatments compared to ambient controls. Although a few studies have observed changes in the crystalline structure of aragonite in response to elevated $p \mathrm{CO}_{2}$, there is no consensus on the effect of OA on calcification in this genus (Ries et al. 2009, Price et al. 2011, Sinutok et al. 2011, 2012, Comeau et al. 2013b, Campbell et al. 2014, Hofmann et al. 2014, Johnson et al. 2014, Vogel et al. 2015b).

One factor which may confound Halimeda responses to elevated $p \mathrm{CO}_{2}$ is irradiance. There have been few studies incorporating irradiance in OA studies (Vogel et al. 2015b) regardless of the fact that this species is adapted to large variations in irradiance. For example, some species live at depths of up to $150 \mathrm{~m}$, while others grow just beneath the sea surface (Hillis-Colinvaux 1986, Blair \& Norris 1988, Littler et al. 1989, Multer \& Clavijo 1989). There is an interaction of exposure to a range of $\mathrm{pH}$ and irradiance in the field. Seawater $\mathrm{pH}$ is higher and more variable on the surface (Sabine et al. 2005, Hofmann et al. 2011) under high irradiance as a result of metabolic activity compared to deeper low irradiance sites where $\mathrm{pH}$ is lower and more constant (Sabine et al. 2005). Even at depth, however, irradiance has been suggested to be important for calcification (Goreau 1963, Böhm 1973, Borowitzka \& Larkum 1976a, Jensen et al. 1985, Littler et al. 1988, de Beer \& Larkum 2001, Beach et al. 2003, Vroom et al. 2003, El-Manawy \& Shafik 2008). Thus, irradiance should be considered when making predictions about the tolerance of this genus to OA.

We examined the effects of $p \mathrm{CO}_{2}$ levels projected for the year 2100 on $H$. discoidea photophysiology, calcification and crystal morphology under sub-saturating and saturating irradiance. The formation of crystals (primary and secondary) and their morphology (density and width) in newly formed segments on adult thalli across $p \mathrm{CO}_{2}$ and irradiance treatments 
were examined using scanning electron microscopy (SEM). Further, non-living segments from adult thalli that were dried and exposed to high $p \mathrm{CO}_{2}$ were used to discern elevated $p \mathrm{CO}_{2}$ effects on crystal morphology and changes in inorganic content of carbonate sediments generated from $H$. discoidea. We hypothesized that if $H$. discoidea can upregulate photosynthesis under elevated $p \mathrm{CO}_{2}$, the potential negative effects of OA on calcification rates may be accommodated in high irradiance treatments. Secondary crystals formed by new segments under low irradiance may exhibit narrower widths under elevated $p \mathrm{CO}_{2}$ if photosynthesis does not counter greater $\mathrm{CO}_{2}$ flux to the IUS. Under this scenario, fewer micro-anhedral carbonates $(<1 \mu \mathrm{m})$ would form as primary crystals are subject to higher dissolution without re-precipitation. However, if primary crystals preferentially dissolve under elevated $p \mathrm{CO}_{2}$ and re-precipitate during the day, micro-anhedral carbonates may become dominant. Non-living segments would also be subject to greater dissolution under elevated $p \mathrm{CO}_{2}$ as $\Omega_{\mathrm{Ar}}$ approach undersaturation, particularly if other decomposing biota (e.g. endolithic micro-biota) are enhanced by greater inorganic carbon availability. These hypotheses and ideas were evaluated in shortterm physiological assays and aquaria experiments (live thalli and non-living segments) using a flowthrough seawater system with coastal Atlantic seawater (Boca Raton, Florida).

\section{MATERIALS AND METHODS}

\section{Experimental design}

Two aquaria experiments were conducted to examine elevated $p \mathrm{CO}_{2}$ and high (saturating) and low (sub-saturating) irradiance effects on Halimeda discoidea photosynthesis, growth, calcification, and crystal morphology. The first experiment followed live thalli development and the second examined changes in mass and crystal morphology of nonliving segments. The live thalli experiment was run as a completely randomized split-plot design with a total of 36 aquaria (9.5 l) randomly assigned to one of 4 levels of $\mathrm{CO}_{2}$ (whole-plot factor) and 2 irradiance treatments (sub-plot factor). Elevated $p \mathrm{CO}_{2}$ treatments were 653, 982 and $1201 \mu \mathrm{atm}$, encompassing low, moderate and high year $2100 \mathrm{CO}_{2}$ emission scenarios, respectively (IPCC 2013). A control was maintained close to ambient coastal ocean $p \mathrm{CO}_{2}$, at $\sim 491 \mu \mathrm{atm}$. The saturating irradiance level for the high irradiance treatment, $300 \mu \mathrm{mol}$ photons $\mathrm{m}^{-2} \mathrm{~s}^{-1}$, was determined using photosynthesis-irradiance $(P: I)$ curves; the low, sub-saturating irradiance level was defined as $30 \%$ of saturation $\left(90 \mu \mathrm{mol}\right.$ photons $\mathrm{m}^{-2}$ $\mathrm{s}^{-1}$ ). High and low irradiance treatments were randomly assigned to sub-plots within each aquarium and were achieved by shading one side of the aquaria with neutral density shade cloth and leaving the other side open at the surface. The live thalli growth experiment took place during November 2013 for $10 \mathrm{~d}$, enough time for new segment production from which newly formed aragonite crystals could be examined using SEM.

In the non-living segment study, a high $p \mathrm{CO}_{2}$ treat-

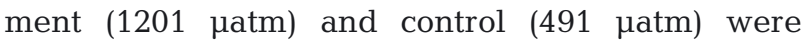
employed and the experiment was run in the dark to simulate sediment conditions without confounding effects of benthic diatoms. Non-living segments were assigned to replicate aquaria $(\mathrm{n}=9)$ in a completely randomized design and the experiment was run for 27 d during May 2014.

\section{Experiment setup and monitoring}

Four header tanks (500 l) were set up with continuous flowing ( 16 $1 \mathrm{~min}^{-1}$ into each tank) coastal Atlantic seawater (Boca Raton, Florida). The ambient tank was bubbled with outside air $\left(\sim 400 \mathrm{ppm} \mathrm{CO}_{2}\right)$ to maintain a low $p \mathrm{CO}_{2}$ control seawater source $(\sim 491$ $\mu \mathrm{atm})$. To achieve high $\mathrm{CO}_{2}$ treatments, $\mathrm{CO}_{2}(100 \%$, $\left.90 \mathrm{l} \mathrm{min}^{-1}\right)$ and compressed air $\left(10 \mathrm{ml} \mathrm{min}^{-1}\right)$ were mixed and continuously added to flowing seawater using mass flow controllers (Sierra Instruments, Smart-Trak 100). Seawater from header tanks continuously delivered $\left(\sim 1.11 \mathrm{~min}^{-1}\right)$ treatment seawater to randomly assigned experimental aquaria $(\mathrm{n}=9$ per treatment) with turnover rates of 7 times $\mathrm{h}^{-1}$. Experimental irradiance $(1000 \mathrm{~W}$ full-spectrum metal halide irradiances, Agrosun( $($ ) ) was maintained on a seasonal light:dark cycle $(11: 13 \mathrm{~h})$ and the experiments were conducted at ambient ocean temperature $\left(\sim 26^{\circ} \mathrm{C}\right)$.

Monitoring of $\mathrm{CO}_{2}$ in header tanks was performed daily in the headspace of an equilibrator using an infrared $\mathrm{CO}_{2}$ analyzer (Qubit S151) calibrated with $\mathrm{CO}_{2}$-free air and a certified $\mathrm{CO}_{2}$ gas standard (400 ppm). Equilibrators were hung above each tank and continuously cycled water from the tank with a small submersible pump. Temperature and $\mathrm{pH}$ (NBS scale) were also measured daily (Orion A211, Ross Electrode) to ensure consistency between the desired treatments in header tanks and replicate experimental aquaria. Total alkalinity (TA) was determined at 
the beginning of the experiment (Titrando ${ }^{\circledR}$ Metrohm) certified by $\mathrm{pH}$ and alkalinity reference material (CRM) (Andrew Dickson Lab, Scripps Institute of Oceanography). Biologically induced changes in TA in aquaria were not a concern because total replenishment of seawater from header tanks occurred every $8 \mathrm{~min}$, ensuring that organisms did not biologically modify seawater chemistry. There was also a very large volume:biomass (algal) ratio in aquaria that precluded any algal effect on water chemistry. Alkalinity, temperature, conductivity (YSI 3100) and $\mathrm{pH}$ data were used to calculate dissolved inorganic carbon (DIC) components and saturation state of aragonite (CO2SYS; Pierrot et al. 2006) for each treatment.

\section{Sample field collections}

H. discoidea whole thalli ( $~ 0.5$ to $1.0 \mathrm{~g}$ ) were collected at $3 \mathrm{~m}$ depth from a nearshore reef $\left(26^{\circ} 19.62^{\prime} \mathrm{N}\right.$, $80^{\circ} 04.33^{\prime} \mathrm{W}$ ) in November 2013 and immediately transported to the FAU Marine Laboratory in Boca Raton, Florida. Specimens were maintained for $6 \mathrm{~d}$ in aquaria under running seawater and saturating irradiance $\left(300 \mu \mathrm{mol}\right.$ photons $\left.\mathrm{m}^{-2} \mathrm{~s}^{-1}\right)$. Thalli (144 total) were randomly placed within replicate aquaria $(\mathrm{n}=$ 9) without sediment, 2 sample replicates per aquaria, and allowed to acclimate to experimental irradiance and $\mathrm{CO}_{2}$ treatments for $3 \mathrm{~d}$ before the experiment commenced.

Non-living segments were collected at the same location as above. Adult thalli with predominantly unpigmented segments were collected. These unpigmented segments were air-dried at room temperature to constant weight. Mesh satchels were constructed to hold several $(\sim 0.25 \mathrm{~g})$ dried non-living unpigmented segments, weighed and randomly allocated to aquaria $(\mathrm{n}=9)$ with the highest $p \mathrm{CO}_{2}$ treatments (1201 $\mu \mathrm{atm})$ and ambient seawater controls for $27 \mathrm{~d}$.

\section{Physiological, growth and structural response metrics}

Photosynthesis

Photosynthesis and respiration rates of thalli were measured by oxygen evolution and consumption, respectively, at the end of the experiment using an $\mathrm{O}_{2}$ electrode system under controlled ambient temperature $\left(26^{\circ} \mathrm{C}\right)$ (ChloroLab 3, Hansatech; Holbrook et al. 1988, Reiskind et al. 1988, Reiskind \& Bowes
1991, Hofmann et al. 2012a,b). Whole H. discoidea thalli ( 0.5 to $1.0 \mathrm{~g}$ ) were dark adapted ( $20 \mathrm{~min})$ and placed into the Chlorolab chamber containing $15 \mathrm{ml}$ of seawater from the respective $\mathrm{CO}_{2}$ treatment. The Chlorolab O2View software was programmed to measure respiration for 4 min followed by 2 min at 9 increasing irradiance levels $(25,50,75,100,200,300$, 500,700 and $900 \mu \mathrm{mol}$ photons $\mathrm{m}^{-2} \mathrm{~s}^{-1}$ ). Incubation times were selected as the minimum that provided steady-state $\mathrm{O}_{2}$ flux at each irradiance level and in the dark. Net photosynthetic oxygen production and consumption rates $\left(P_{\text {net }}, \mathrm{nmol} \mathrm{O}_{2} \mathrm{~min}^{-1}\right)$ were normalized to fresh tissue mass (g). $P: I$ curves were generated using the hyperbolic tangent model (Jassby \& Platt 1976): $P_{\text {net }}=P_{\max } \times \tanh \left(\alpha I / P_{\max }\right)+R_{\mathrm{d}}$ and photosynthetic parameters were calculated in accordance with Lobo et al. (2013). These included: efficiency $(\alpha$, ascending slope at limiting irradiance), maximum photosynthetic rate $\left(P_{\max }\right.$, asymptotic estimate of maximum net photosynthetic rate), irradiance independent respiration $\left(R_{\mathrm{d}}\right)$ and irradiance compensation point $\left(I_{\mathrm{c}}\right)$.

Live thalli calcification and new segment production

Whole thalli net calcification rates $\left(G_{\text {net }}\right)$ were determined using the buoyant weight technique, a sensitive $( \pm 0.1 \mathrm{mg})$ non-destructive method to estimate calcification and/or dissolution in calcifying species (Jokiel et al. 1978). Buoyant weights of all thalli were measured after the initial acclimation period and at the end of the incubation experiment to examine relative $\mathrm{CaCO}_{3}$ weight change over time. Specific calcification rates were calculated by normalizing buoyant weight change to final thalli dry weight. All thalli remained intact throughout the duration of the experiment, verified with photography. Thus changes in weight did not have to account for segment turnover.

New segment production on adult thalli was tracked using photographs taken at the beginning and end of the experiment. These data were used to calculate new segment production and identify new segments from different treatments that could be assessed for changes in tissue mineral content and crystal morphology using SEM.

\section{Non-living segments mass loss}

Mass loss rates of non-living segments were determined by weighing segments before and after the 
27 d experiment. Mesh satchels containing segments were removed from aquaria, dried at room temperature and reweighed. Mass loss rates were normalized to initial dry weight of intact non-living segments.

Segment tissue inorganic content

Tissue inorganic content of live thalli and nonliving segments (assumed to be primarily $\mathrm{CaCO}_{3}$ ) was determined at the end of the 10 and $27 \mathrm{~d}$ aquaria experiments, respectively. Segments were rinsed in distilled water to remove salts, dried at $60^{\circ} \mathrm{C}$ to constant weight and acidified (5\% of $12 \mathrm{~N} \mathrm{HCl}$ ) until no effervescence formed following acid addition. Postacidified segments were rinsed with distilled water, dried at $60^{\circ} \mathrm{C}$ and weighed. The inorganic content was determined from weight differences in the preacidified and post-acidified segments.

\section{SEM sample preparation and microscopy}

Ultrastructure of new segments formed from live thalli was analyzed using SEM. Samples were fixed in $2 \%$ glutaraldehyde in sodium cacodylate buffered seawater, dehydrated in a graded series of ethanol and dried in hexamethyldisilazane (HMDS). Dehydrated tissue samples were fractured along the vertical mid-plane and mounted on aluminum stubs covered with carbon adhesive tabs with the tissue interior exposed at the surface, sputter coated with a palladium target and observed in an FEI XL 30 Field Emission ESEM/SEM (University of Miami Center for Advanced Microscopy). Even though the IUS is a 3-dimensional space, SEM images in 2-dimensions can be used to estimate the density of Halimeda IUS crystals (Robbins et al. 2009, Wizemann et al. 2015b). The IUS $\left(\sim 2 \mu \mathrm{m}^{2}\right)$ of primary utricles of triplicate thalli for each treatment were located and randomly selected $(\mathrm{n}=3$ ) for secondary crystal (IUS interior) counts and width measurements (total $\sim 20$ to 30 crystals) using image processing software (ImageJ v1.47). Non-living segments were also fractured and examined using SEM as described above.

\section{Statistical analyses}

Two-way split-plot ANOVAs (SAS v4.3) were used to determine the significance of $p \mathrm{CO}_{2}$ and irradiance treatments on photophysiology and calcification responses in $H$. discoidea. These included $P$ : I curve parameters, net calcification rates of whole thalli, and $\mathrm{CaCO}_{3}$ content and crystal densities and widths of newly formed segments. The fixed factors were $p \mathrm{CO}_{2}$ (whole plot) and irradiance (split-plot), and aquaria was a random factor nested within $p \mathrm{CO}_{2}$. Post hoc comparisons were conducted using Dunnett's test to identify significant $p \mathrm{CO}_{2}$ effects relative to ambient levels (491 $\mu \mathrm{atm})$. Maximum photosynthetic rates were unaffected by irradiance and its interaction with $p \mathrm{CO}_{2}$, so we pooled low and high irradiance grown thalli to identify significant differences (Dunnett's test) between the elevated $p \mathrm{CO}_{2}$ and the ambient treatments. Frequency of new segment production among replicate live thalli was calculated based on binary probability distributions. Effects of $p \mathrm{CO}_{2}$ on non-living segment mass loss rates and $\mathrm{CaCO}_{3}$ content were evaluated using 1way ANOVAs with $p \mathrm{CO}_{2}$ as a fixed factor and aquaria a random factor nested within $p \mathrm{CO}_{2}$ (SAS v4.3). Differences in seawater carbonate chemistry parameters $\left(p \mathrm{CO}_{2}, \mathrm{pH}, \mathrm{TA}, \Omega_{\mathrm{Ar}}\right)$ between treatments were compared with a 1-way ANOVA. Assumptions for normality (Shapiro-Wilk test, p < 0.01) and homoscedasticity of variance (Levene's test, p < 0.01) were verified prior to parametric testing. Significance levels for all statistical tests were set at $\mathrm{p}<0.05$ unless otherwise stated.

\section{RESULTS}

\section{Experimental conditions}

The mean daily $p \mathrm{CO}_{2}$ in the ambient treatment

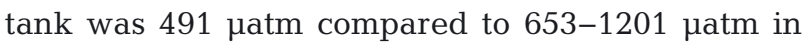
the elevated $p \mathrm{CO}_{2}$ treatments (Table 1). The corresponding daily mean $\mathrm{pH}$ of the ambient treatment was 8.06, and pH ranged from 7.74 to 8.00 in the elevated $p \mathrm{CO}_{2}$ treatments. Differences between mean $p \mathrm{CO}_{2}$ and $\mathrm{pH}$ in treatment tanks were significant $(\mathrm{p}<$ $0.01)$. Temperature $\left(\sim 26^{\circ} \mathrm{C}\right)$ and salinity ( 36 ppt) did not differ significantly among treatment tanks or aquaria. Average seawater TA measurements of the 4 treatment tanks ranged from 2266 to 2298, with no significant differences among replicate measurements from all treatments. The average \% error between the predicted $\left(2330 \mu \mathrm{mol} \mathrm{kg}{ }^{-1}\right)$ and measured values for experimental seawater TA was $\pm 3 \%$. Calculated mean values for $\Omega_{\mathrm{Ar}}$ of elevated $p \mathrm{CO}_{2}$ treatments (982 and $1201 \mu \mathrm{atm}$ ) were consistent with the year 2100 projection $\left(\Omega_{\mathrm{Ar}} \sim 1.8\right.$; Fabry et al. 2008$)$, and differed significantly $(\mathrm{p}<0.01)$ between all $p \mathrm{CO}_{2}$ treatments including ambient seawater. 
Table 1. Measured and calculated carbonate chemistry parameters from experimental treatment tanks. Partial pressure of $\mathrm{CO}_{2}\left(p \mathrm{CO}_{2}\right), \mathrm{pH}_{\mathrm{NBS}}$ (NBS scale) and temperature $(T)$ were measured daily $(\mathrm{n}=10)$ and used to compute (CO2SYS, Pierrot et al. 2006) $p \mathrm{CO}_{2}, \mathrm{HCO}_{3}{ }^{-}, \mathrm{CO}_{3}{ }^{2-}$ and the aragonite saturation state $\left(\Omega_{\mathrm{Ar}}\right)$. Salinity and total alkalinity (TA) measurements $(\mathrm{n}=3)$ were conducted at the beginning of the experiment. Data are means (SD). Dissociation constants for carbonate determined by Mehrbach et al. (1973), refit by Dickson \& Millero (1987)

\begin{tabular}{|c|c|c|c|c|c|c|c|c|}
\hline \multirow{2}{*}{ 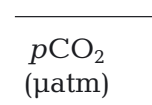 } & \multirow[b]{2}{*}{$\mathrm{pH}_{\mathrm{NBS}}$} & \multirow{2}{*}{$\begin{array}{c}\text { Measured }- \\
T \\
\left({ }^{\circ} \mathrm{C}\right)\end{array}$} & \multirow[b]{2}{*}{$\begin{array}{l}\text { Salinity } \\
\text { (ppt) }\end{array}$} & \multirow[b]{2}{*}{$\begin{array}{c}\text { TA } \\
\left.(\mu \mathrm{mol} \mathrm{kg})^{-1}\right)\end{array}$} & \multirow[b]{2}{*}{$\begin{array}{c}\mathrm{CO}_{2} \\
\left(\mu \mathrm{mol} \mathrm{kg}{ }^{-1}\right)\end{array}$} & \multirow{2}{*}{$\begin{array}{c}\mathrm{Calcu}_{3}^{-} \\
\left(\mu \mathrm{mol} \mathrm{kg}{ }^{-1}\right)\end{array}$} & \multirow{2}{*}{$\begin{array}{l}\text { ated } \\
\qquad \mathrm{CO}_{3}^{2-} \\
\left(\mu \mathrm{mol} \mathrm{kg}{ }^{-1}\right)\end{array}$} & \multirow[b]{2}{*}{$\Omega_{\mathrm{Ar}}$} \\
\hline & & & & & & & & \\
\hline $491(27)$ & $8.06(0.02)$ & $26.2(0.5)$ & $36.0(0.0)$ & 2266 (9) & $15.0(0.1)$ & 1830 (9) & $176(0)$ & $2.79(0.01)$ \\
\hline $653(44)$ & $8.00(0.02)$ & $26.0(0.5)$ & $35.9(0.2)$ & 2286 (14) & $17.9(0.1)$ & $1897(10)$ & $158(1)$ & $2.51(0.02)$ \\
\hline $982(105)$ & $7.86(0.03)$ & $26.0(0.5)$ & $36.2(0.7)$ & $2298(28)$ & $25.9(0.2)$ & $1999(22)$ & $122(3)$ & $1.92(0.04)$ \\
\hline 1201 (97) & $7.74(0.02)$ & $26.0(0.5)$ & $36.3(0.2)$ & 2296 (11) & $35.2(0.1)$ & 2061 (9) & 95 (1) & $1.51(0.01)$ \\
\hline
\end{tabular}

\section{Photosynthesis}

Halimeda discoidea $P_{\max }$ significantly differed between ambient and elevated $p \mathrm{CO}_{2}$ treatments $(\mathrm{p}<$ 0.05 , Table 2); $P_{\max }$ at $1201 \mu \mathrm{atm} p \mathrm{CO}_{2}$ was significantly higher than at ambient $p \mathrm{CO}_{2}(491 \mu \mathrm{atm})$ levels

Table 2. Results of 2-way split-plot ANOVAs including $\mathrm{CO}_{2}$ (whole-plot factor), irradiance (sub-plot factor) and their interaction on Halimeda discoidea photosynthesis, calcification and growth responses: $P_{\max }=$ production at saturating irradiance; $\alpha=$ photosynthetic efficiency at sub-saturating irradiance; $I_{\mathrm{C}}=$ compensation irradiance, $R_{\mathrm{d}}=$ dark respiration; $T-G_{\text {net }}=$ total $\mathrm{CaCO}_{3}$ production; $N-G_{\text {net }}=\mathrm{CaCO}_{3}$ production normalized to final thalli dry weight; $\% \mathrm{CaCO}_{3}=$ new segment inorganic content. Bold $=$ significant values at $\mathrm{p}<0.05$

\begin{tabular}{|c|c|c|c|c|}
\hline Parameter & Effect & df & $F$ & p-value \\
\hline \multirow[t]{3}{*}{$P_{\max }$} & $\mathrm{CO}_{2}$ & 3,32 & 3.62 & 0.023 \\
\hline & Irradiance & 1,31 & 0.12 & 0.733 \\
\hline & $\mathrm{CO}_{2} \times$ Irradiance & 3,31 & 0.50 & 0.688 \\
\hline \multirow[t]{3}{*}{$\alpha$} & $\mathrm{CO}_{2}$ & 3,32 & 0.87 & 0.466 \\
\hline & Irradiance & 1,31 & 0.68 & 0.416 \\
\hline & $\mathrm{CO}_{2} \times$ Irradiance & 3,31 & 1.57 & 0.216 \\
\hline \multirow[t]{3}{*}{$I_{\mathrm{C}}$} & $\mathrm{CO}_{2}$ & 3,32 & 2.01 & 0.133 \\
\hline & Irradiance & 1,31 & 9.69 & 0.004 \\
\hline & $\mathrm{CO}_{2} \times$ Irradiance & 3,31 & 5.01 & 0.006 \\
\hline \multirow[t]{3}{*}{$R_{\mathrm{d}}$} & $\mathrm{CO}_{2}$ & 3,32 & 0.14 & 0.933 \\
\hline & Irradiance & 1,31 & 0.99 & 0.326 \\
\hline & $\mathrm{CO}_{2} \times$ Irradiance & 3,31 & 0.55 & 0.653 \\
\hline \multirow[t]{3}{*}{$T-G_{\text {net }}$} & $\mathrm{CO}_{2}$ & 3,32 & 1.13 & 0.353 \\
\hline & Irradiance & 1,32 & 0.00 & 0.953 \\
\hline & $\mathrm{CO}_{2} \times$ Irradiance & 3,32 & 1.76 & 0.175 \\
\hline \multirow[t]{3}{*}{$N-G_{\text {net }}$} & $\mathrm{CO}_{2}$ & 3,32 & 1.50 & 0.233 \\
\hline & Irradiance & 1,32 & 0.47 & 0.499 \\
\hline & $\mathrm{CO}_{2} \times$ Irradiance & 3,32 & 2.52 & 0.075 \\
\hline \multirow[t]{3}{*}{$\% \mathrm{CaCO}_{3}$} & $\mathrm{CO}_{2}$ & 3,30 & 0.18 & 0.910 \\
\hline & Irradiance & 1,12 & 18.90 & 0.001 \\
\hline & $\mathrm{CO}_{2} \times$ Irradiance & 3,12 & 0.53 & 0.668 \\
\hline
\end{tabular}

( $\mathrm{p}<0.05$, Fig. 1, Table 3 ). There was also a significant main effect of irradiance and its interaction with $p \mathrm{CO}_{2}$ on $I_{\mathrm{c}}(\mathrm{p}<0.01$, Table 2$)$ with irradiance compensation points lower on average in the low irradiance treatment (Table 3). Specifically, $I_{\mathrm{c}}$ was significantly lower ( $p<0.05$, Table 3 ) in thalli exposed to

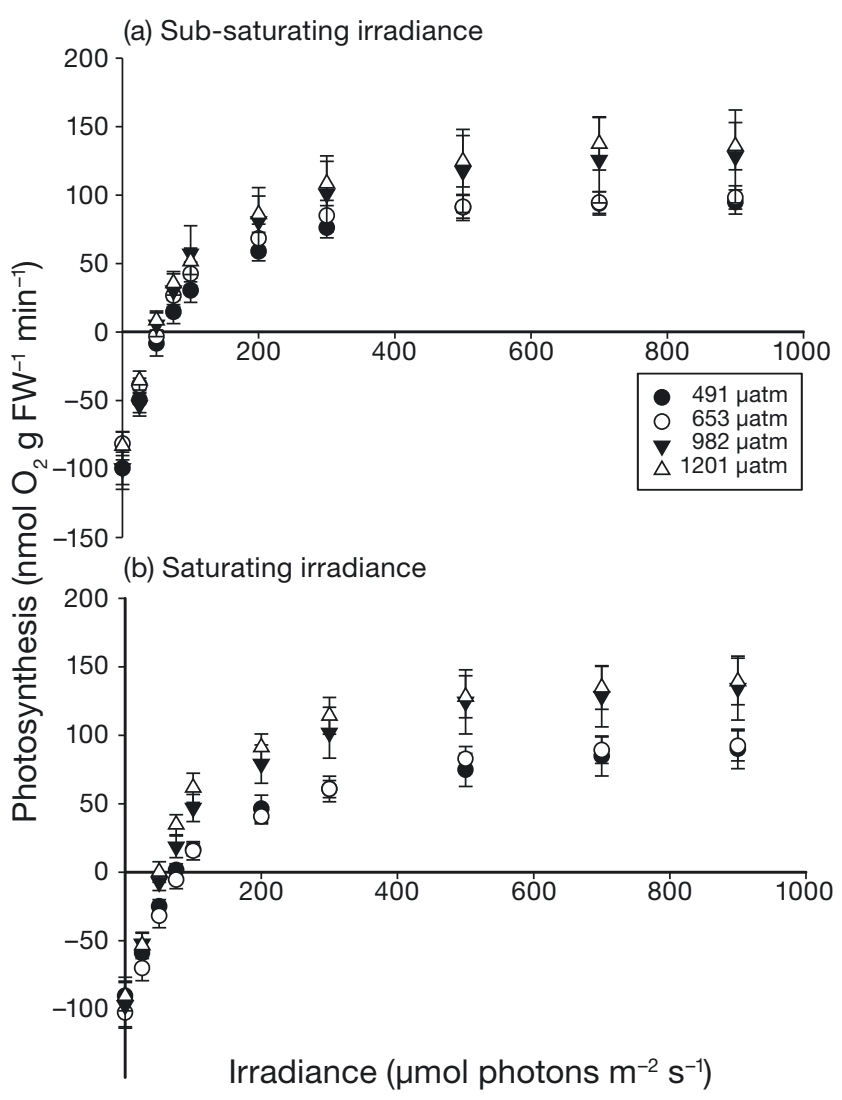

Fig. 1. Photosynthesis-irradiance $(P: I)$ curves for Halimeda discoidea exposed to 4 levels of $\mathrm{CO}_{2}$ partial pressure $\left(p \mathrm{CO}_{2}\right.$; $491,653,982,1201 \mu \mathrm{atm}$ ) and (a) low, sub-saturating irradiance $\left(90 \mu \mathrm{mol}\right.$ photons $\left.\mathrm{m}^{-2} \mathrm{~s}^{-1}\right)$ and (b) high, saturating (300 $\mu \mathrm{mol}$ photons $\mathrm{m}^{-2} \mathrm{~s}^{-1}$ ) irradiance treatments for $10 \mathrm{~d}$. $P: I$ curves were generated in seawater from respective $p \mathrm{CO}_{2}$ treatment tanks. Data are means $\pm \mathrm{SE}$ of 9 replicates 
Table 3. Photosynthetic parameters for Halimeda discoidea after $10 \mathrm{~d}$ exposure to 4 levels of $\mathrm{CO}_{2}$ partial pressures $\left(p \mathrm{CO}_{2} ; \mu \mathrm{atm}\right)$ and saturating $\left(300 \mu \mathrm{mol}\right.$ photons $\left.\mathrm{m}^{-2} \mathrm{~s}^{-1}\right)$ and sub-saturating irradiance $\left(90 \mu \mathrm{mol}\right.$ photons $\left.\mathrm{m}^{-2} \mathrm{~s}^{-1}\right): P_{\max }=$ production at saturating irradiance; $\alpha=$ photosynthetic efficiency at sub-saturating irradiance $I_{\mathrm{C}}=$ compensation irradiance $; R_{\mathrm{d}}=$ dark respiration. Data are means $(\mathrm{SE})$ of 9 replicates

\begin{tabular}{|clcccc|}
\hline \multicolumn{3}{|c}{ Treatments } & \multicolumn{5}{c|}{ Photosynthesis parameters } \\
$p \mathrm{CO}_{2}$ & Irradiance & $P_{\max }$ & $\alpha$ & $I_{\mathrm{c}}$ & $R_{\mathrm{d}}$ \\
\hline 491 & Low & $87(8)$ & $1.6(0.2)$ & $65(8)$ & $-92(10)$ \\
653 & Low & $92(9)$ & $1.5(0.2)$ & $62(6)$ & $-76(9)$ \\
982 & Low & $96(10)$ & $1.7(0.2)$ & $55(6)$ & $-85(12)$ \\
1201 & Low & $121(19)$ & $1.5(0.2)$ & $68(13)$ & $-73(9)$ \\
Average & & $99(2)$ & $1.6(0.1)$ & $63(3)$ & $-82(4)$ \\
491 & High & $79(13)$ & $1.2(0.2)$ & $94(11)$ & $-85(13)$ \\
653 & High & $85(9)$ & $1.3(0.1)$ & $91(12)$ & $-93(9)$ \\
982 & High & $118(22)$ & $1.6(0.3)$ & $66(5)$ & $-88(14)$ \\
1201 & High & $128(15)$ & $1.8(0.2)$ & $54(5)$ & $-90(11)$ \\
Average & & $103(11)$ & $1.5(0.1)$ & $76(8)$ & $89(2)$ \\
\hline
\end{tabular}

653 uatm $p \mathrm{CO}_{2}$ under low compared to high irradiance. Among the high irradiance exposed individuals, the lowest $I_{\mathrm{c}}$ was observed under the highest $p \mathrm{CO}_{2}$ level with significant differences between the $1201 \mu \mathrm{atm}$ and ambient levels $(\mathrm{p}<0.05$, Table 3$)$, indicating that higher $\mathrm{CO}_{2}$ availability lowered photosynthesis to respiration compensation points in high irradiance exposed individuals. This reduction in compensation did not appear to be a response to high irradiance stress, as respiration rates were simi- lar across irradiance and $p \mathrm{CO}_{2}$ treatment combinations (Tables $2 \& 3$ ). While $P_{\max }$ reflected elevated $p \mathrm{CO}_{2}$ and $I_{\mathrm{c}}$ to $p \mathrm{CO}_{2}$ and irradiance treatments in which they were grown, based on ANOVA analysis $\alpha$ was similar between $p \mathrm{CO}_{2}$ and irradiance treatments including their interaction (Table 2). Regression analyses, however, indicate at high irradiance there were significant correlations ( $\mathrm{R}^{2}$ range 0.98 to 0.99 ) between increasing $p \mathrm{CO}_{2}, P_{\max }, \alpha$, and decreasing $I_{\mathrm{c}}$ with increasing $p \mathrm{CO}_{2}$ (Table 3).

\section{Live thalli calcification rates}

Total $\mathrm{CaCO}_{3}$ production $\left(T-G_{\text {net }}\right)$ and $\mathrm{CaCO}_{3}$ production normalized to thalli dry weight $\left(N-G_{\text {net }}\right)$ were similar across all $p \mathrm{CO}_{2}$ and irradiance treatment combinations (Tables $2 \& 4$ ). No significant differences in calcification rates were observed among treatments, but rates were positive with the exception of the $653 \mu \mathrm{atm} p \mathrm{CO}_{2}$ treatment under high irradiance (Table 4).

\section{Segment production and inorganic content}

The production of new calcified segments was primarily affected by irradiance with a significantly lower proportion of replicate thalli producing new segments in the high irradiance treatment $(p<0.01$, Table 4). Approximately $50 \%$ fewer thalli produced

Table 4. Calcification metrics of Halimeda discoidea in response to treatments at 4 levels of $p \mathrm{CO}_{2}(491,653,982,1201 \mu \mathrm{atm})$ and saturating $\left(300 \mu \mathrm{mol}\right.$ photons $\left.\mathrm{m}^{-2} \mathrm{~s}^{-1}\right)$ and sub-saturating irradiance $\left(90 \mu \mathrm{mol}\right.$ photons $\left.\mathrm{m}^{-2} \mathrm{~s}^{-1}\right)$. Net calcification rates of whole thalli in replicate aquaria $(\mathrm{n}=9)$ shown as total $\mathrm{CaCO}_{3}$ production $\left(T-G_{\mathrm{net}}\right)$ and $\mathrm{CaCO}_{3}$ production normalized to final thalli dry weight $\left(N-G_{n e t}\right)$. Segment production rates per replicate aquaria $(n=9)$ shown as number of thalli with new segments and \% replicates that had new segments after $10 \mathrm{~d}$ in treatments. Inorganic content of new segments per replicate aquaria $(\mathrm{n}=9)=\% \mathrm{CaCO}_{3}$. Secondary aragonite crystal density and widths $(\mathrm{n}=3)$ determined by scanning electron microscopy in control (491 $\mu \mathrm{atm})$ and elevated (982 and $1201 \mu \mathrm{atm}) \mathrm{pCO}_{2}$ treatments. Data are means (SE). nd: not determined

\begin{tabular}{|c|c|c|c|c|c|c|c|c|}
\hline \multicolumn{2}{|c|}{ Treatments } & \multicolumn{2}{|c|}{$\begin{array}{l}\text { Whole thalli } \\
\text { net calcification rates }\end{array}$} & \multicolumn{2}{|c|}{$\begin{array}{c}\text { Segment } \\
\text { production }\end{array}$} & \multirow{2}{*}{$\begin{array}{c}\text { New segment } \\
\text { inorganic content } \\
\left(\% \mathrm{CaCO}_{3}\right)\end{array}$} & \multicolumn{2}{|c|}{$\begin{array}{c}\text { Secondary } \\
\text { aragonite crystals }\end{array}$} \\
\hline $\begin{array}{l}p \mathrm{CO}_{2} \\
\text { ( } \mu \text { atm) }\end{array}$ & Irradiance & $\begin{array}{c}T-G_{\text {net }} \\
\left(\mathrm{mg} \mathrm{d}^{-1}\right)\end{array}$ & $\begin{array}{c}N-G_{\text {net }} \\
\left(\mathrm{mg} \mathrm{g}^{-1} \mathrm{~d}^{-1}\right)\end{array}$ & No. & $\%$ new & & $\begin{array}{c}\text { Density } \\
\left(\text { No. } \mu \mathrm{m}^{-2}\right)\end{array}$ & $\begin{array}{l}\text { Width } \\
(\mu \mathrm{m})\end{array}$ \\
\hline 491 & Low & $0.1(0.9)$ & $1(16)$ & $8.0(1.0)$ & 89 (11) & $69(2)$ & $6.1(0.6)$ & $0.21(0.04)$ \\
\hline 653 & Low & $0.5(0.7)$ & 4 (9) & $7.0(1.0)$ & 78 (11) & $73(4)$ & nd & nd \\
\hline 982 & Low & $1.4(0.8)$ & 26 (15) & $6.5(1.5)$ & $72(17)$ & $66(2)$ & $7.1(0.1)$ & $0.18(0.01)$ \\
\hline 1201 & Low & $0.9(1.2)$ & $9(21)$ & $9.0(0.0)$ & $100(0)$ & $73(5)$ & $6.1(0.6)$ & $0.22(0.02)$ \\
\hline Average & & $0.7(0.4)$ & $10(8)$ & $7.6(0.6)$ & $85(6)$ & $70(2)$ & $6.4(0.3)$ & $0.22(0.00)$ \\
\hline 491 & High & $1.0(0.4)$ & 24 (10) & $4.5(0.5)$ & $50(6)$ & $53(8)$ & $6.4(1.2)$ & $0.23(0.02)$ \\
\hline 653 & High & $-0.7(0.6)$ & $-10(10)$ & $2.5(2.5)$ & $28(28)$ & $56(4)$ & nd & nd \\
\hline 982 & High & $1.9(0.9)$ & 29 (13) & $2.5(0.5)$ & $28(6)$ & $64(8)$ & $9.8(4.0)$ & $0.19(0.01)$ \\
\hline 1201 & High & $0.7(0.6)$ & $0(6)$ & $3.5(0.5)$ & $39(6)$ & $55(9)$ & $8.1(0.7)$ & $0.17(0.02)$ \\
\hline Average & & $0.7(0.3)$ & $11(6)$ & $3.3(0.5)$ & $36(5)$ & $56(2)$ & $8.2(1.0)$ & $0.20(0.02)$ \\
\hline
\end{tabular}


(a)

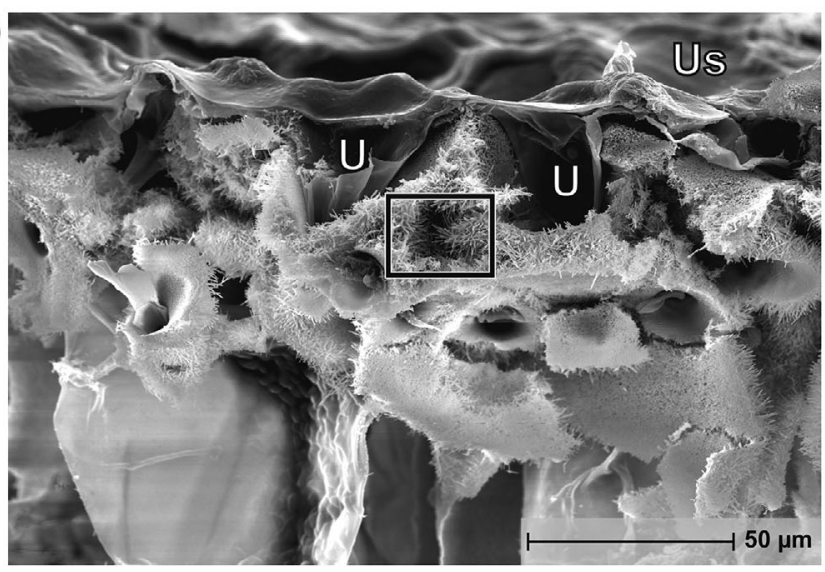

(b)

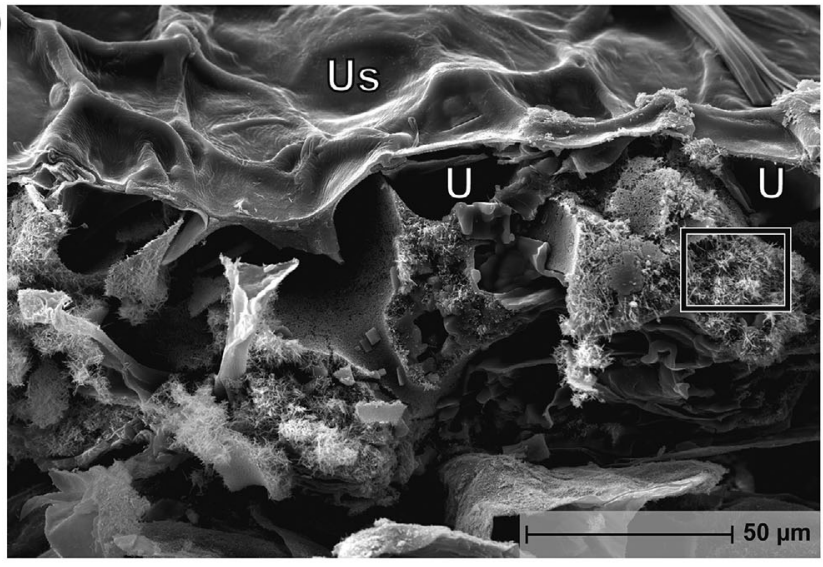

(c)

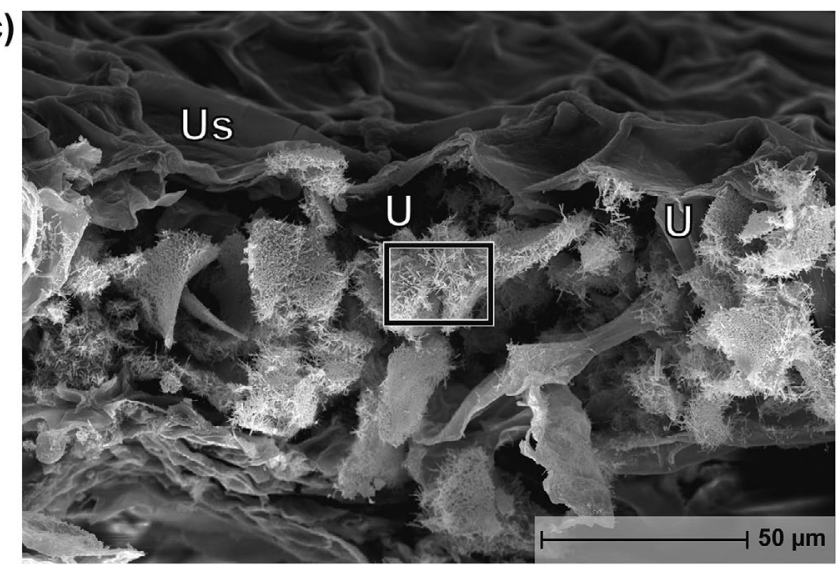

(d)

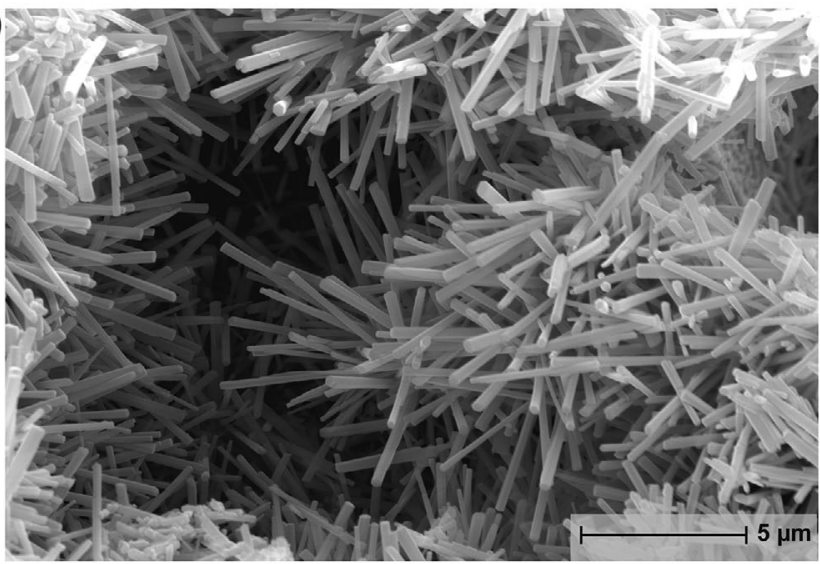

(e)

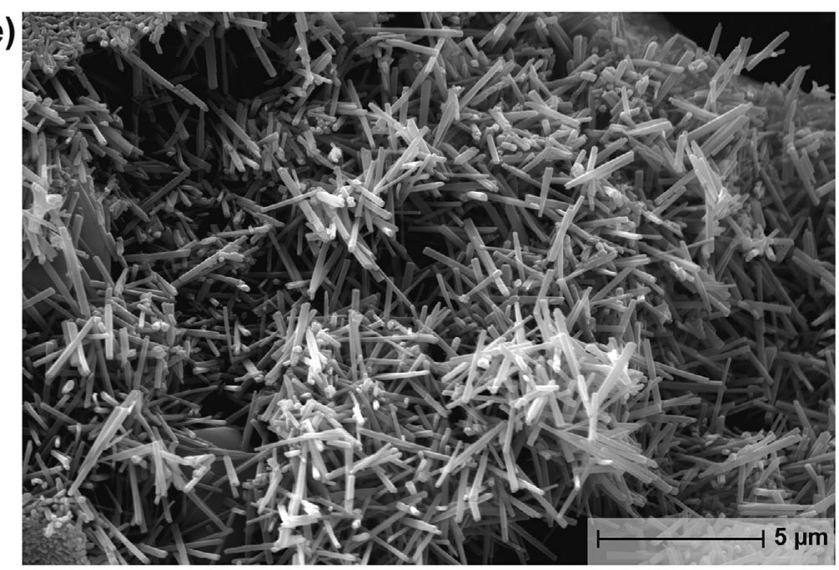

(f)

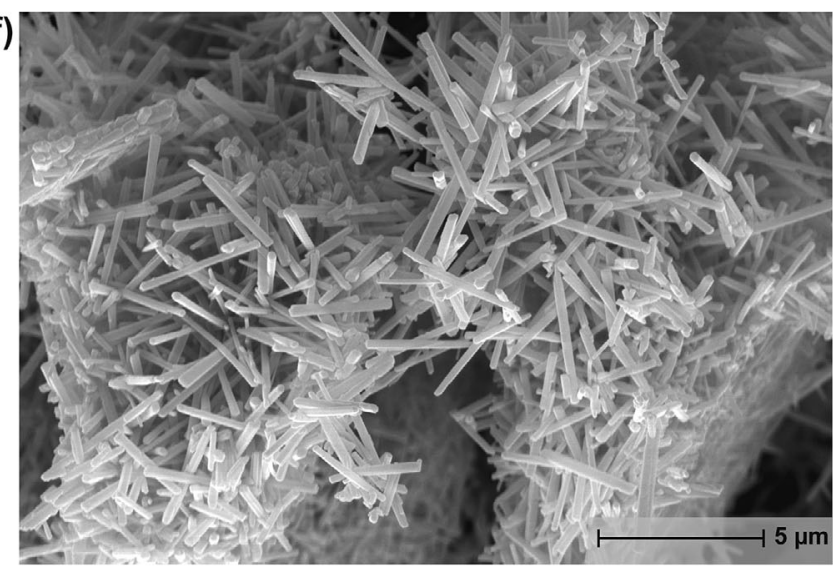

Fig. 2. Halimeda discoidea primary interutricular space (IUS) aragonite crystal structure in newly formed $(<10 \mathrm{~d})$ segments grown under low, sub-saturating irradiance $\left(90 \mu \mathrm{mol}\right.$ photons $\left.\mathrm{m}^{-2} \mathrm{~s}^{-1}\right)$ and $(\mathrm{a}, \mathrm{d})$ ambient $(491 \mu \mathrm{atm}),(\mathrm{b}, \mathrm{e})$ moderate $(982$ patm) and (c,f) high $(1201 \mu \mathrm{atm}) \mathrm{CO}_{2}$ partial pressure $\left(p \mathrm{CO}_{2}\right)$. (a-c) Images of the IUS at 1250x resolution depict cell walls of the dehydrated utricle (U) and utricle surface (Us). (d-f) Higher magnification (10000x) of the boxes in panels a-c showing primary IUS crystals

new segments under high compared to low irradiance. We also observed that thalli grown under high irradiance were visibly lighter (light green) than those grown under low irradiance (dark green).

Irradiance also affected inorganic production $\left(\% \mathrm{CaCO}_{3}\right)$ within new segments $(\mathrm{p}<0.01$, Tables $2 \&$
4). Segments grown at high irradiance contained $\sim 14 \%$ less inorganic content than those produced under low irradiance (Table 4). Despite these differences in inorganic content, all new segments were at least $50 \%$ calcified (Table 4 ), and no significant differences were found between $p \mathrm{CO}_{2}$ treatments (Table 2). 
(a)

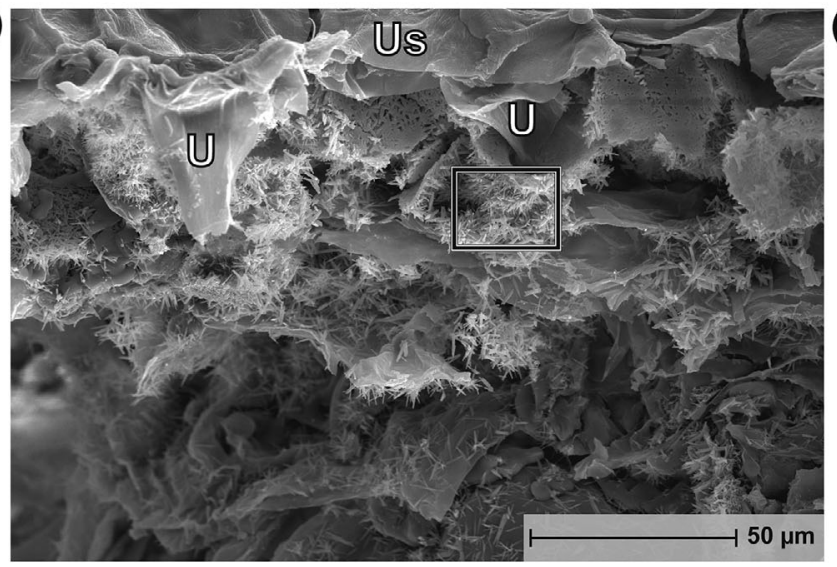

(b)

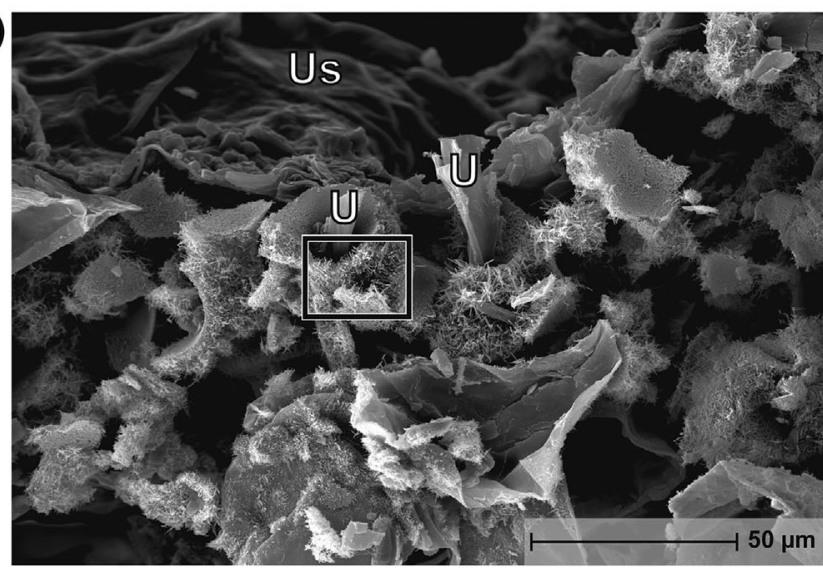

(c)

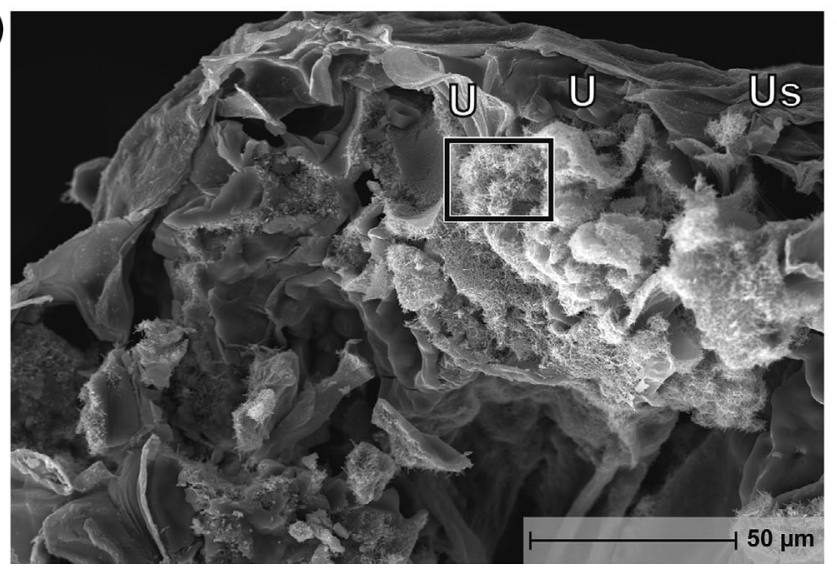

(d)

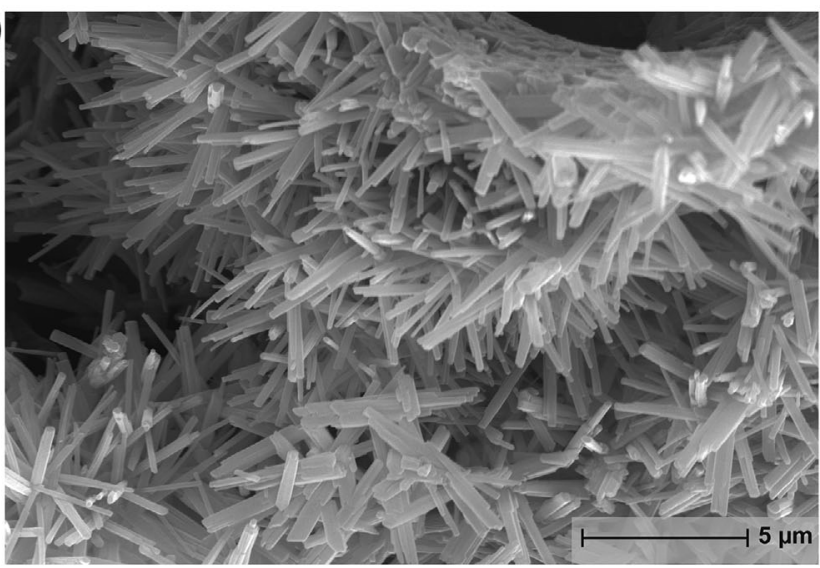

(e)

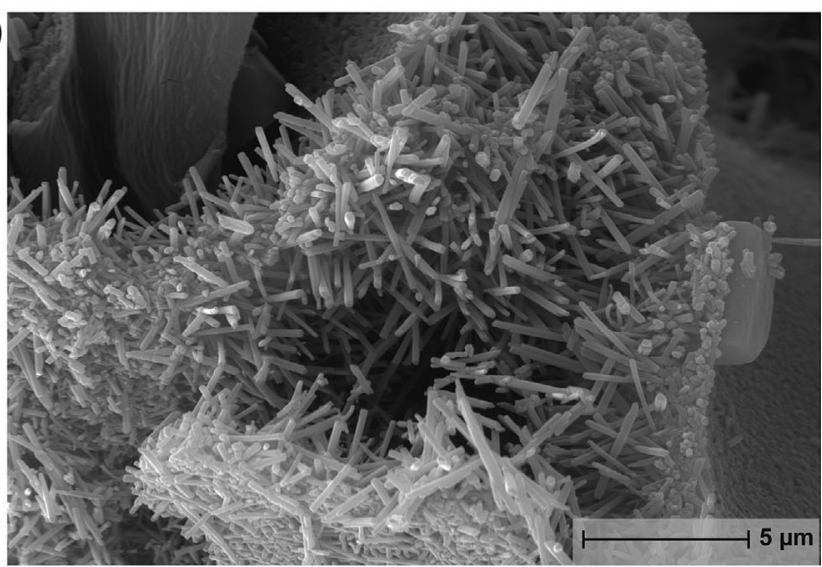

(f)

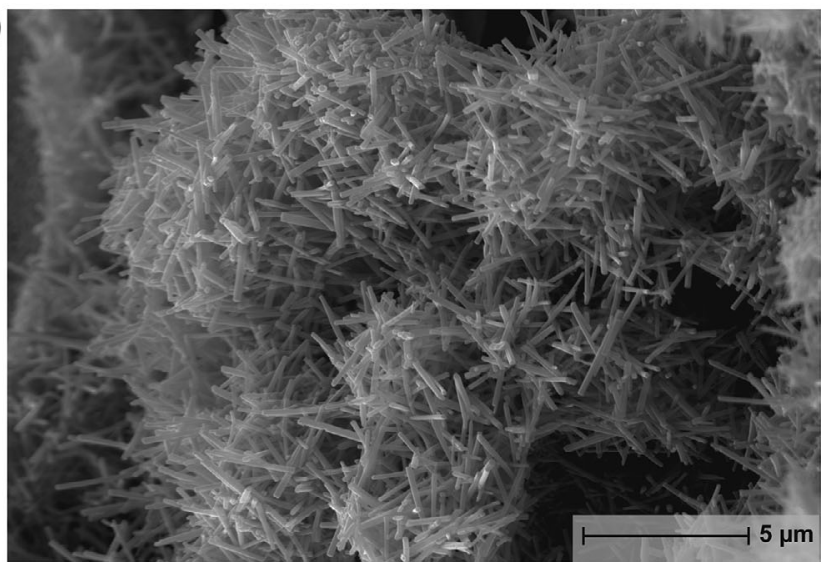

Fig. 3. Halimeda discoidea primary interutricular space (IUS) aragonite crystal structure in newly formed $(<10 \mathrm{~d})$ segments grown under high, saturating irradiance $\left(300 \mu \mathrm{mol}\right.$ photons $\left.\mathrm{m}^{-2} \mathrm{~s}^{-1}\right)$ and $(\mathrm{a}, \mathrm{d})$ ambient $(491 \mu \mathrm{atm}),(\mathrm{b}, \mathrm{e})$ moderate $(982 \mu \mathrm{atm})$ and (c,f) high (1201 ratm) $p \mathrm{CO}_{2}$. Images magnified (a-c) 1250x and (d-f) 10000x. See Fig. 2 for details

\section{Aragonite crystal formation in newly formed segments}

SEM imaging of new segments produced under ambient and elevated $p \mathrm{CO}_{2}$ treatments (982 and $1201 \mu \mathrm{atm}$ ) and at low (Fig. 2) and high (Fig. 3) irradiances revealed no significant treatment effects on aragonite crystal production. Images of the IUS of primary utricles revealed highly organized crystals in multiple stages of development. Along the smooth surface where remnant primary utricles retracted from the IUS, short (1 to $2 \mu \mathrm{m}$ ), primary needles (Figs. $2 \mathrm{a}-\mathrm{c} \& 3 \mathrm{a}-\mathrm{c})$ were adjacent to the utricle wall, and in some cases a distinct rim of micron-sized $(<1 \mu \mathrm{m})$ 
anhedral crystals were apparent (Fig. 3e, lower right corner). Longer $(2-9 \mu \mathrm{m})$, un-oriented secondary aragonite crystals with characteristic needle shape also populated the internal space of the primary IUS (Figs. 2d-f \& 3d-f).

Secondary aragonite crystals that precipitated in new segments grown under 491, 982 and $1201 \mu \mathrm{atm}$ $p \mathrm{CO}_{2}$ treatments exhibited similar characteristics and morphologies (Figs. 2d-f \& 3d-f). Secondary crystals did not completely fill the IUS showing their early stage of segment formation. The resulting open spaces appear as dark contrast in the middle of the IUS (Figs. 2a-f \& 3a-f). Secondary crystal density was approximately 6 to 10 crystals $\mu \mathrm{m}^{-2}$ in the primary IUS across all treatments (Table 4) with relatively low variance (coefficient of variance $=0.23$ ) and no significant treatment effect. The mean widths of the secondary crystals fell within a narrow range from 0.17 to $0.23 \mu \mathrm{m}$ across treatments, indicating that the conditions in the primary IUS, regardless of irradiance or external $p \mathrm{CO}_{2}$ levels, were conducive for crystal initiation and growth in newly formed segments. Visualization of SEM images, quantitative data on secondary crystal density and morphology, as well as net positive calcification rates of whole thalli, indicate that crystal dissolution in new segments formed during the experiment was likely insignificant at $\Omega_{\mathrm{Ar}}>1.5$ even though external $p \mathrm{CO}_{2}$ concentrations were $>1000 \mu$ atm (Table 1).

\section{Non-living segment mass loss rates and aragonite crystal structure}

No significant morphology changes were observed in non-living segment crystals after $27 \mathrm{~d}$ in the dark at elevated $p \mathrm{CO}_{2}$. However, crystal widths were slightly more narrow at elevated $\mathrm{pCO}_{2}(0.17 \mu \mathrm{m})$ compared to ambient seawater $(0.21 \mu \mathrm{m})$. Even though crystals widths were significantly lower

Table 5. Non-living Halimeda discoidea segment characteristics: change in dry mass normalized to initial dry mass $(\mathrm{n}=9)$, percent calcium carbonate $(\mathrm{n}=9)$, and aragonite crystal densities and widths $(n=2)$ after $27 \mathrm{~d}$ at elevated

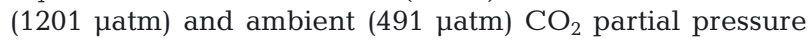
$\left(p \mathrm{CO}_{2}\right)$ treatments. Data are means (SE)

\begin{tabular}{|ccccc|}
\hline $\begin{array}{c}p \mathrm{CO}_{2} \\
(\mu \mathrm{atm})\end{array}$ & $\begin{array}{c}\text { Mass } \\
\text { loss rate } \\
\left(\mathrm{mg} \mathrm{g}^{-1} \mathrm{~d}^{-1}\right)\end{array}$ & $\begin{array}{c}\text { Inorganic } \\
\text { content }\end{array}$ & \multicolumn{2}{c|}{$\begin{array}{c}\text { Aragonite crystals } \\
\text { Density }\end{array}$} \\
\hline 491 & $-9(1)$ & $63.0(2.5)$ & $6.9(0.6)$ & $0.21(0)$ \\
$\left(\mathrm{NaCO}_{3}\right)$ & Width \\
1201 & $-11(1)$ & $62.2(2.1)$ & $7.7(0.2)$ & $0.17(0)$ \\
\hline
\end{tabular}

under elevated $p \mathrm{CO}_{2}(\mathrm{p}<0.05$, Table 5), width measurements were within the range $(0.17$ to $0.23 \mu \mathrm{m})$ observed for new crystals formed in live thalli segments across $p \mathrm{CO}_{2}$ and irradiance treatments. On average, the density of aragonite crystals of nonliving segments was approximately 7 to 8 crystals $\mu \mathrm{m}^{-2}$ with no differences between $p \mathrm{CO}_{2}$ treatments (Table 5). Mass loss rates normalized to dry thalli weight were also similar between ambient and elevated $p \mathrm{CO}_{2}$ treated non-living segments. In addition, elevated $p \mathrm{CO}_{2}$ did not change the $\mathrm{CaCO}_{3}$ content of non-living segments relative to controls (Table 5).

SEM images of non-living segments after $27 \mathrm{~d}$ at elevated $p \mathrm{CO}_{2}$ did not exhibit visual differences in crystal form compared to controls (Fig. 4) and showed an abundance of intact crystals in both treatments. Aragonite crystals in the non-living segments, which were fully mature when removed from the adult thalli, more completely filled the IUS (Fig. 4c,d) compared to those of young newly formed segments (Figs. $2 \& 3 \mathrm{a}-\mathrm{c}$ ). These consolidated crystals remained in tightly-bound conglomerations (Fig. 4a,b), remnants of the intact IUS, even after $27 \mathrm{~d}$ in the elevated $p \mathrm{CO}_{2}$ treatment.

\section{DISCUSSION}

In the present study, new Halimeda discoidea segments formed primary and secondary aragonite crystals in all treatments, including elevated $p \mathrm{CO}_{2}(1201$ $\mu \mathrm{atm})$, low $\mathrm{pH}$ (7.7) and $\Omega_{\mathrm{Ar}}$ (1.5) approaching undersaturation $(<1)$. Our SEM images elucidated primary crystal formation along the utricle-IUS boundary in all treatments; however, the distinction between primary and secondary crystallization may not be certain as primary crystals are subject to dissolution (Wizemann et al. 2014). The crystals we identified as primary were within the lower end of the length ranges ( 1 to $2 \mu \mathrm{m}$ ) identified for $H$. opuntia ( 2 to $3 \mu \mathrm{m}$ ) and $H$. incrassata ( 1 to $3 \mu \mathrm{m}$ ) by Wizemann et al. (2015b) and Macintyre \& Reid (1995), respectively. Longer secondary aragonite crystals partially filled the IUS. These were approximately half the length $(2$ to $9 \mu \mathrm{m}$ ) of secondary crystals described for $H$. opuntia $(>20 \mu \mathrm{m})$ and $H$. incrassata $(6$ to $12 \mu \mathrm{m})$. The smaller secondary crystal size may be characteristic of $H$. discoidea, which is not as heavily calcified in the IUS as $H$. opuntia or $H$. incrassata. Our smaller secondary crystal lengths could also be related to early developmental stages of the newly emerged segments $(<10 \mathrm{~d})$, as secondary needles are known to elongate and widen with segment age (Wizemann et 

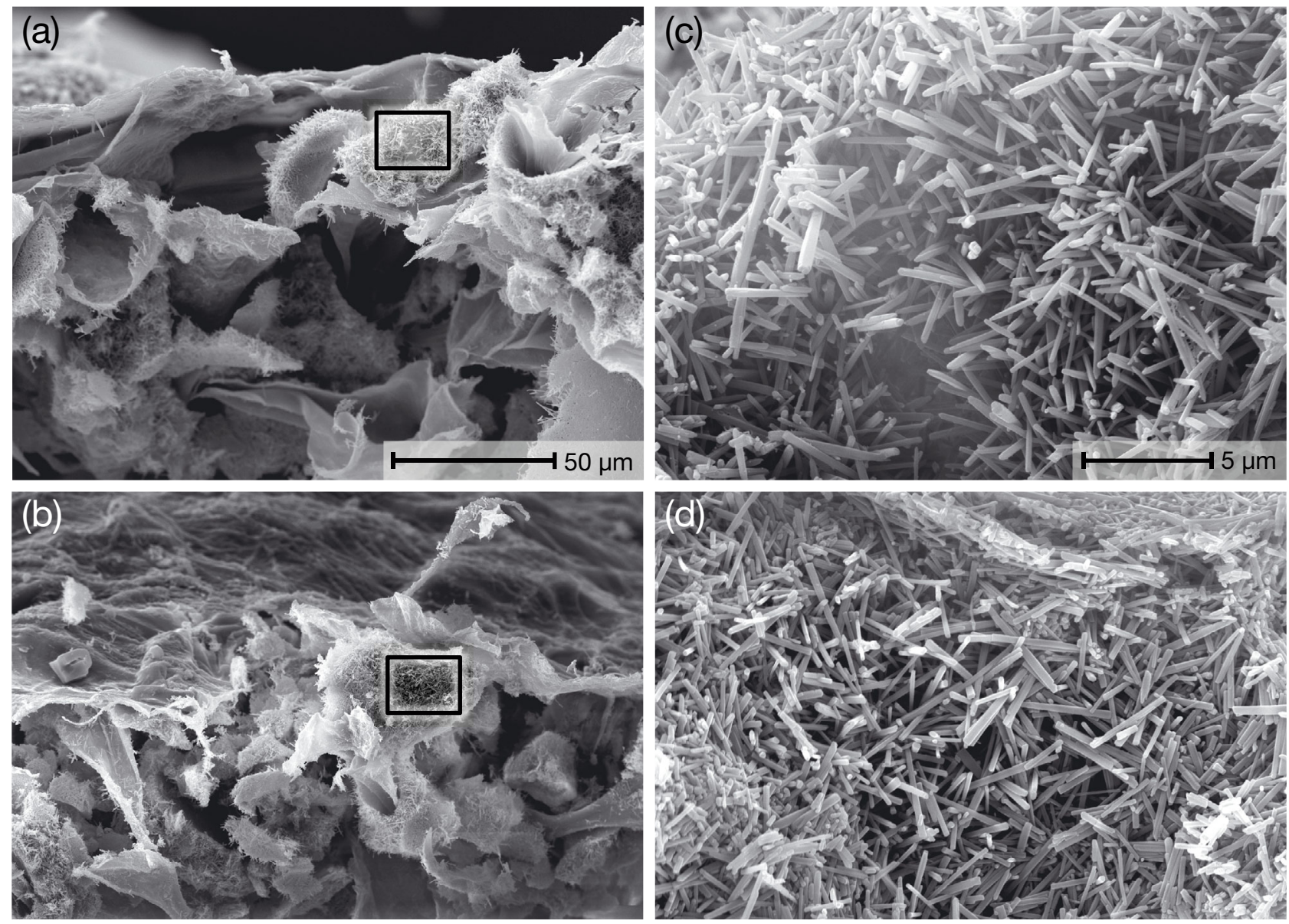

Fig. 4. Halimeda discoidea interutricular space aragonite crystal clusters in non-living segments exposed to (a,c) ambient $(491 \mu \mathrm{atm})$ and $(\mathrm{b}, \mathrm{d})$ high $(1201 \mu \mathrm{atm}) \mathrm{CO}_{2}$ partial pressure $\left(p \mathrm{CO}_{2}\right)$ for $27 \mathrm{~d}$. Image magnification: $(\mathrm{a}, \mathrm{b}) 1250 \times$ and $(\mathrm{c}, \mathrm{d}) 10000 \times$ (corresponding to boxed area in $[\mathrm{a}, \mathrm{b}]$ ). The aragonite crystal clusters show similar individual aragonite crystal forms

al. 2014). Longer secondary crystals observed by Wizemann et al. (2015b) were in segments up to $45 \mathrm{~d}$ old, while Macintyre \& Reid (1995) harvested adult thalli from the field and ages of segments were not determined. Halimeda crystals within the IUS can vary by size and exhibit a range of characteristics within the same species and individual depending on location, age and metabolic activity (Hillis-Colinvaux 1980, Macintyre \& Reid 1995, Wizemann et al. 2015b, this study). While we observed variability in crystal formation among individual thalli and segments, for example the infilling of the IUS, there were no discernable changes in crystal width or density across $p \mathrm{CO}_{2}$ or irradiance treatments. Therefore, the utricle cell walls retained properties necessary for primary aragonite crystal formation and subsequent precipitation of secondary crystals in the IUS, regardless of $p \mathrm{CO}_{2}$ or irradiance examined herein (90 and 300 $\mu \mathrm{mol}$ photons $\mathrm{m}^{-2} \mathrm{~s}^{-1}$ ). This was the case even though H. discoidea primary utricles are weakly fused com- pared to other Halimeda species (Macintyre \& Reid 1995), and thus could be susceptible to the transport of $\mathrm{H}^{+}$into the IUS under OA.

No apparent difference in the amount of recrystallized primary aragonite crystals was observed in $H$. discoidea under elevated $p \mathrm{CO}_{2}$ compared to control treatments or under high and low irradiance. Based on our SEM images from $H$. discoidea, microanhedral carbonates were clearly present at the utricle-IUS boundary intermixed with intact primary crystals (Figs. 2e \& 3e). In other SEM images, microanhedral carbonates were not as apparent and intact crystals extended to the utricle-IUS boundary, exemplified in one of the elevated $p \mathrm{CO}_{2}$ grown segment images (Fig. 5). Thus, although primary crystal formation occurred across treatments, there was no discernable evidence for a treatment effect on dissolution and/or re-precipitation of these crystals. In contrast, Wizemann et al. (2015b) found microanhedral carbonates formed less readily in $H$. opun- 
(a)

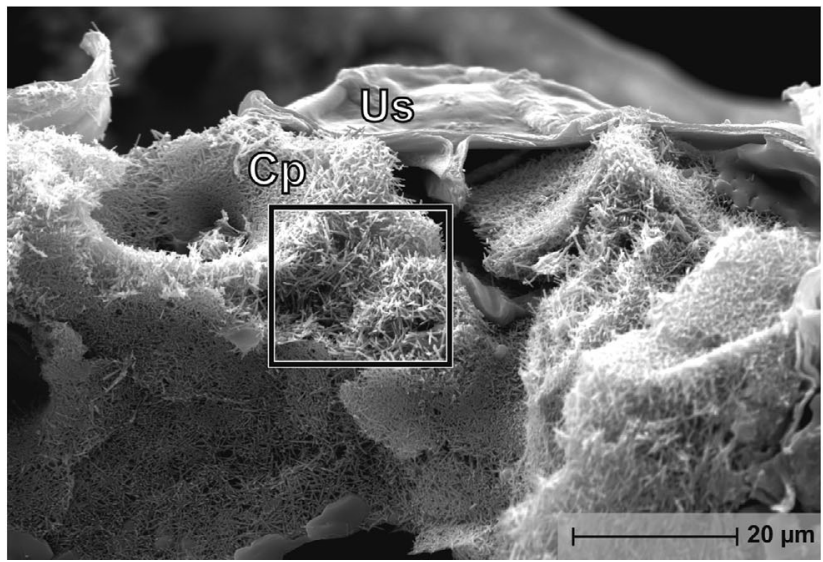

(b)

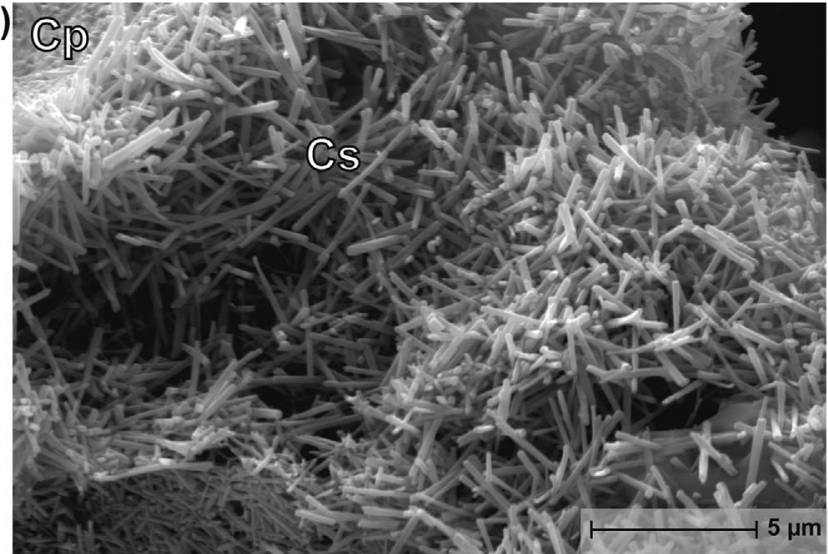

Fig. 5. Scanning electron microscope image of Halimeda discoidea from the highest $\mathrm{CO}_{2}$ partial pressure $\left(p \mathrm{CO}_{2}\right)$ treatment $(1201 \mu \mathrm{atm})$ and high, saturating irradiance $\left(300 \mu \mathrm{mol}\right.$ photons $\left.\mathrm{m}^{-2} \mathrm{~s}^{-1}\right)$, showing primary crystals $(\mathrm{Cp})$ along the edge where the primary utricle was located just below the utricle surface (Us). Radiating from the Cp are secondary un-oriented aragonite crystals (Cs). No well-formed micro-anhedral crystal formation can be seen at the utricle-interutricular space boundary. Image magnification: (a) $2500 \times$ and (b) $10000 \times$

tia segments under modestly elevated $\mathrm{pCO}_{2}$ (650 $\mu \mathrm{atm})$ levels relative to controls and attributed this observation to IUS undersaturation $\left(\Omega_{\mathrm{Ar}}<1\right)$ compounded by high respiration rates. We speculate that high photosynthetic rates and/or low respiration rates in new apical segments $(<10 \mathrm{~d})$ may account for the lack of micro-anhedral carbonate or primary cementation responses to elevated $p \mathrm{CO}_{2}$ in $\mathrm{H}$. discoidea. Perhaps there is also a wide species-specific diversity in micro-anhedral crystal formation. Halimeda discoidea has been shown to possess minimal micro-anhedral carbonate development under ambient seawater conditions compared to some Halimeda species that are more heavily calcified (Macintyre \& Reid 1995). The significance and mechanisms controlling micro-anhedral crystal formation are presently unclear and further research on their formation and potential interaction with elevated $p \mathrm{CO}_{2}$ under OA is warranted.

Although we did not find statistical or observational changes in the crystallized structure of aragonite under elevated $p \mathrm{CO}_{2}$, several OA studies report crystal changes in several species of Halimeda. Synthesizing results of these studies, including our own, shows $50 \%$ of the investigations found an increase in crystal density and a majority ( $83 \%$ ) found a reduction in crystal width (Table 6). However, varying crystal responses to elevated $p \mathrm{CO}_{2}$ may have resulted from differences in experimental seawater carbonate chemistry (minimum $\Omega_{\mathrm{Ar}}$ ranged 0.7 to 3.8 ; Table 6), exposure time (9 to $60 \mathrm{~d}$ ), age of the segment and/or crystal type related to stage of formation. For example, distinguishing between primary and secondary crystals can be critical because secondary crystals are thought to be more resistant to dissolution (Macintyre \& Reid 1995). This has been proposed because of the location of secondary crystals within the central region of the IUS where they are remote from active respiratory processes at the utricle cell wall. While some studies distinguish between primary (Wizemann et al. 2015b) and secondary crystal stage (this study), others do not (Robbins et al. 2009, Sinutok et al. 2011), making comparisons across studies difficult.

The absence of a $p \mathrm{CO}_{2}$ effect on crystal formation in $H$. discoidea may be attributable to positive photosynthetic responses under greater $\mathrm{CO}_{2}$ availability. Our ANOVA results indicated a significant increase in $P_{\max }$ under elevated $p \mathrm{CO}_{2}$ in the $P: I$ experiments on adult thalli that were acclimated to both low and high irradiance in the aquaria study. In thalli grown under high irradiance, a strong positive linear relationship was found between $p \mathrm{CO}_{2}$ level and $P_{\max }\left(\mathrm{R}^{2}\right.$ $=0.99)$ as well as $\alpha\left(R^{2}=0.98\right)$, and a negative linear relationship between $p \mathrm{CO}_{2}$ level and $I_{\mathrm{c}}\left(\mathrm{R}^{2}=0.98\right)$. These data support an upregulation of photophysiology in high irradiance-adapted Halimeda with increasing $p \mathrm{CO}_{2}$. In a review of the literature, however, photosynthetic enhancement under elevated $p \mathrm{CO}_{2}$ is not well documented and some results are contradictory (Table 6). Only Hofmann et al. (2014) found higher relative electron transport rate by fluorescence $\left(\mathrm{rETR}_{\max }\right)$ at elevated $p \mathrm{CO}_{2}(1700 \mu \mathrm{atm})$ compared to ambient for $H$. opuntia incubated at low irradiance $\left(50 \mu \mathrm{mol}\right.$ photons $\left.\mathrm{m}^{-2} \mathrm{~s}^{-1}\right)$. In another study with identical low-irradiance conditions, rETR $_{\max }$ 
Table 6. Synthesis of studies evaluating elevated $\mathrm{CO}_{2}$ partial pressure $\left(p \mathrm{CO}_{2}\right)$ effects on photosynthesis and calcification in the Halimeda genus based on lab and mesocosm experiments. Positive (+), negative $(-)$, parabolic $(p)$, and no effects $(0)$ shown for net calcification $\left(G_{\text {net }}\right)$, aragonite crystal density and width, and productivity $\left(P_{\text {net, }}\right.$ or electron transport rate by fluorescence [rETR max $\left.]\right)$. Experimental conditions include: irradiance ( $\mu \mathrm{mol}$ photons $\mathrm{m}^{-2} \mathrm{~s}^{-1}$; PAR), $p \mathrm{CO}_{2}$ range ( $\mu$ atm unless otherwise noted), saturation state of aragonite $\left(\Omega_{\mathrm{Ar}}\right)$ and duration of experiment (d)

\begin{tabular}{|c|c|c|c|c|c|c|c|c|c|c|c|}
\hline Species & $G_{\text {net }}$ & \multicolumn{3}{|c|}{ - Responses —_ } & \multicolumn{6}{|c|}{$\longrightarrow$ Experimental conditions } & Study \\
\hline H. discoidea & 0 & 0 & 0 & + & $90 / 350$ & 491 & $653-1201$ & 2.8 & $1.5-2.5$ & 10 & This study \\
\hline H. macroloba & $\begin{array}{l}-^{\mathrm{b}} \\
- \\
0\end{array}$ & 0 & $-{ }^{\mathrm{e}}$ & - & $\begin{array}{l}300 \\
300 \\
700\end{array}$ & $\begin{array}{l}319^{\mathrm{h}} \\
381 \\
385^{\mathrm{h}}\end{array}$ & $\begin{array}{l}662-2445^{\mathrm{h}} \\
1208 \\
525-2119^{\mathrm{h}}\end{array}$ & $\begin{array}{l}4.0 \\
3.9 \\
3.6\end{array}$ & $\begin{array}{l}1.2-3.3 \\
2.0 \\
1.1-3.0\end{array}$ & $\begin{array}{l}35 \\
35 \\
14\end{array}$ & $\begin{array}{l}\text { Sinutok et al. (2011) } \\
\text { Sinutok et al. (2012) } \\
\text { Comeau et al. (2013b) }\end{array}$ \\
\hline H. minima & - & & & & 700 & $385^{\mathrm{h}}$ & $525-2119^{\mathrm{h}}$ & 3.6 & $1.1-3.0$ & 14 & Comeau et al. (2013b) \\
\hline H. opuntia & $\begin{array}{l}- \\
- \\
-^{\mathrm{c}} \\
0 \\
0\end{array}$ & + & - & $\begin{array}{l}- \\
0 \\
+ \\
0\end{array}$ & $\begin{array}{c}1733^{\mathrm{f}} \\
150^{\mathrm{g}} \\
868^{\mathrm{g}} \\
331 \\
55 \\
35 / 150 \\
150\end{array}$ & $\begin{array}{c}340^{\mathrm{j}} \\
440^{\mathrm{i}} \\
1116 \\
318 \\
415 \\
427 \\
412\end{array}$ & $\begin{array}{c}1684^{\mathrm{j}} \\
946^{\mathrm{i}} \\
2178 \\
611-2379 \\
1705 \\
1073 \\
648\end{array}$ & $\begin{array}{l}3.9 \\
2.5 \\
0.2 \\
3.6 \\
5.7 \\
3.3 \\
3.1\end{array}$ & $\begin{array}{c}1.2 \\
1.4 \\
0.1 \\
0.9-2.2 \\
3.8 \\
1.7 \\
2.3\end{array}$ & $\begin{array}{l}21 \\
14 \\
17 \\
58 \\
28 \\
16 \\
45\end{array}$ & $\begin{array}{l}\text { Robbins et al. (2009) } \\
\text { Price et al. (2011 } \\
\text { Johnson et al. (2014) } \\
\text { Campbell et al. (2014) } \\
\text { Hofmann et al. (2014) } \\
\text { Vogel et al. (2015b) } \\
\text { Wizemann et al. (2015b) }\end{array}$ \\
\hline H. simulans & $--^{\mathrm{d}}$ & & & & 350 & 430 & $1022-2430$ & 2.7 & $0.8-1.5$ & 49 & Campbell et al. (2014) \\
\hline H. taenicola & $\begin{array}{l}- \\
0 \\
0\end{array}$ & & & $\begin{array}{l}0 \\
0 \\
0\end{array}$ & $\begin{array}{l}150^{g} \\
178^{g} \\
572^{g}\end{array}$ & $\begin{array}{c}440^{\mathrm{i}} \\
1330 \\
400\end{array}$ & $\begin{array}{r}946^{\mathrm{i}} \\
1365 \\
2314\end{array}$ & $\begin{array}{l}2.5 \\
0.9 \\
2.4\end{array}$ & $\begin{array}{l}1.4 \\
0.7 \\
0.8\end{array}$ & $\begin{array}{c}14 \\
9 \\
15\end{array}$ & $\begin{array}{l}\text { Price et al. (2011 } \\
\text { Johnson et al. (2014) } \\
\text { Johnson et al. (2014) }\end{array}$ \\
\hline $\begin{array}{l}\text { H. tuna } \\
\text { a-e Significant (p } \\
{ }^{\mathrm{f}} \text { Converted wat } \\
{ }^{\mathrm{g}} \text { Natural irradi } \\
{ }^{\mathrm{h}} \text { Converted Pa } \\
{ }^{\mathrm{i}} \mathrm{ppm} \text {; } \\
{ }^{\mathrm{j}} \text { Calculated usi }\end{array}$ & $\begin{array}{l}<0.0 \\
\text { tt to } \mu \\
\text { ance a } \\
\text { to } \mu \text { at } \\
\text { ng } 230\end{array}$ & $\begin{array}{l}+ \\
\text { 5) calc } \\
\text { mol ph } \\
\text { at noor } \\
\text { tm by } \\
00 \text { for }\end{array}$ & $\mathrm{m}$ & ing 1 & $\begin{array}{l}\text { ses detectec } \\
\text { dividing by } \\
\text { and median }\end{array}$ & $\begin{array}{l}\text { at: }{ }^{\mathrm{a}} \geq 10 \\
.3 \text { and }\end{array}$ & $\begin{array}{l}1684^{\mathrm{j}} \\
069 \operatorname{\mu atm}_{i}^{\mathrm{b}}= \\
\text { assuming Pf }\end{array}$ & $\begin{array}{l}445 \mu \mathrm{a} \\
\text { after }\end{array}$ & $\begin{array}{c}1.2 \\
{ }^{\mathrm{c}} \geq 611 \mu \mathrm{c} \\
\mathrm{z} \text { \& Zeige }\end{array}$ & $\begin{array}{c}21 \\
\operatorname{tm}_{i}{ }^{d} \geq 102 \\
(2010)\end{array}$ & $\begin{array}{l}\text { Robbins et al. (2009) } \\
22 \mu_{\text {atm }}{ }^{\text {e }} \geq 662 \mu \mathrm{atm}\end{array}$ \\
\hline
\end{tabular}

was also stimulated by elevated $p \mathrm{CO}_{2}(1500 \mu \mathrm{atm})$ in the calcareous red macroalgae Corallina officinalis (Yildiz et al. 2013). While these studies observed increases in $\mathrm{rETR}_{\max }$ with high $\mathrm{CO}_{2}$ availability, the majority of $\mathrm{CO}_{2}$-enrichment studies indicate a negative or no photosynthesis response to elevated $\mathrm{CO}_{2}$ in calcifying macroalgae (Anthony et al. 2008, Semesi et al. 2009, Gao \& Zheng 2010, Hofmann et al. 2012b, Egilsdottir et al. 2013, Martin et al. 2013, Noisette et al. 2013, Johnson et al. 2014, reviewed in Hofmann \& Bischof 2014). Based on a review of several Halimeda species there was only a modest or no potential for photosynthesis to mitigate negative OA effects on calcification (Table 6; Price et al. 2011, Sinutok et al. 2011, 2012, Johnson et al. 2014, Vogel et al. 2015b). Vogel et al. (2015b) found no calcification change in $H$. opuntia at sub-saturating $\left(35 \mu \mathrm{mol}\right.$ photons $\mathrm{m}^{-2}$ $\left.\mathrm{s}^{-1}\right)$ versus saturating $\left(150 \mu \mathrm{mol}\right.$ photons $\left.\mathrm{m}^{-2} \mathrm{~s}^{-1}\right)$ irra- diance under elevated $p \mathrm{CO}_{2}(1073 \mu \mathrm{atm})$, similar to findings in the present study. We found no significant difference in $H$. discoidea calcification rates under elevated $p \mathrm{CO}_{2}$ at saturating irradiance even though photosynthesis $\left(P_{\max }\right)$ was upregulated and greater photosynthetic efficiency $\left(\alpha, I_{\mathrm{c}}\right)$ was documented under high irradiance in the $P: I$ assays (Table 3 , Fig. 1b).

One explanation for why greater $\mathrm{CO}_{2}$ availability under high irradiance did not elevate calcification rates in $\mathrm{H}$. discoidea adult thalli or $\mathrm{CaCO}_{3}$ content in new segments is that carbon gains from photosynthesis were allocated to organic components of the algae, illustrated by the $15 \%$ higher organic content on average in new segments under high compared to low irradiance. Further, filament cell walls sequestering $\mathrm{CO}_{2}$ from seawater for photosynthesis may not promote $\mathrm{CO}_{2}$ uptake from the IUS directly, and thus 
photosynthesis and calcification may be uncoupled in this regard (reviewed in Koch et al. 2013). Halimeda chloroplasts are known to migrate toward the light (Larkum et al. 2011), thus the photosynthesisdriven $\mathrm{CO}_{2}$ uptake may be remote from the interior cell wall along the IUS (A. Wizemann pers. comm.). While the tissue organic content was greater under high compared to low irradiance, the production of new segments was almost two-fold greater under low irradiance in $H$. discoidea. This pattern was observed not only under artificial irradiance conditions in this study, but also in aquaria experiments with natural solar irradiance in 6 other Halimeda species (Peach et al. unpubl. data). Thus, while there was a photophysiological response in $H$. discoidea to elevated $p \mathrm{CO}_{2}$, particularly after high irradiance acclimation, the higher photosynthetic rate and efficiency did not translate to increased calcification rates of adult thalli or production of new segments. The mechanisms for these irradiance-induced changes in $H$. discoidea development and calcification in live thalli need further examination and may contribute to the range of OA responses reported for the Halimeda genus (Table 6).

In contrast to carbonate crystal stability of live thalli under elevated $p \mathrm{CO}_{2}$, crystals associated with the carbonate sediment produced by $H$. discoidea may be altered by elevated $\mathrm{pCO}_{2}$. We found non-living segments contained more narrow crystals at high (1201 $\mu \mathrm{atm}) p \mathrm{CO}_{2}$ compared to ambient seawater. The idea that OA may cause carbonate loss has been supported in field studies. Fabricius et al. (2011) found greater seawater alkalinity at cold volcanic $\mathrm{CO}_{2}$ (444 to $953 \mu \mathrm{atm}$ ) seeps in Papua New Guinea compared to control sites, indicating a higher net dissolution rate of tropical carbonate sediments from $\mathrm{CO}_{2}$-enriched seawater. Although we found that non-living segments lost mass in the $27 \mathrm{~d}$ aquaria study, aragonite crystals remained relatively intact in both the ambient and elevated $p \mathrm{CO}_{2}$ treatments. We saw a similar response for non-living segments of 3 additional Halimeda species after exposure to elevated $p \mathrm{CO}_{2}(\sim 1000 \mu \mathrm{atm})$ compared to ambient seawater (Peach et al. unpubl. data). The intact structure of individual aragonite crystals within consolidated clusters were likely the remnants of secondary crystals of the IUS. In this moderately calcified species, complete formation of micro-anhedral crystals leading to primary cementation was not observed. This type of calcification is likely responsible for the formation of Halimeda needle muds, rather than larger sedimentary plates (Wizemann et al. 2015a). Based on these data, we suggest that $H$. discoidea will likely continue its contribution to tropical reef sediments, but potentially form finer aragonite needle muds. Additional studies are required to understand how differences in Halimeda species crystal formation and amount of primary cementation will determine how OA may ultimately affect the breakdown of carbonates and the ecological role of this genus in the formation of tropical reef sediments.

Acknowledgements. This research was supported by a grant from FAU's Climate Change Research Initiative and scholarships from the Gordon Gilbert Scholarship Fund, Gumbo Limbo Nature Center and the Broward County Shell Club. Elizabeth Dutra, Theresa Strazisar, Carl Santangelo, Narcissus Smith, Luke Joles and Connor Ryan provided laboratory and field assistance. We thank André Wizemann and 2 anonymous reviewers that provided constructive feedback which significantly improved the manuscript.

\section{LITERATURE CITED}

Alexandersson ET, Milliman JD (1981) Intragranular Mgcalcite cement in Halimeda plates from the Brazilian continental shelf. J Sediment Petrol 51:1309-1314

> Anthony KRN, Kline DI, Diaz-Pulido G, Dove S, HoeghGuldberg O (2008) Ocean acidification causes bleaching and productivity loss in coral reef builders. Proc Natl Acad Sci USA 105:17442-17446

Beach K, Walters L, Vroom P, Smith C, Coyer J, Hunter C (2003) Variability in the ecophysiology of Halimeda spp. (Chlorophyta, Bryopsidales) on Conch Reef, Florida Keys, USA. J Phycol 39:633-643

Blair SM, Norris JN (1988) The deep-water species of Halimeda Lamouroux (Halimedaceae, Chlorophyta) from San Salvador Island, Bahamas: species composition, distribution and depth records. Coral Reefs 6:227-236

Böhm EL (1973) Studies on the mineral content of calcareous algae. Bull Mar Sci 23:177-190

Borowitzka MA (1989) Carbonate calcification in algae: initiation and control. In: Mann S, Webb J, Williams RJP (eds) Biomineralization: chemical and biochemical perspectives. VCH Publications, Weinheim, p 63-94

- Borowitzka MA, Larkum AWD (1976a) Calcification in the green alga Halimeda. II. The exchange of $\mathrm{Ca}^{2+}$ and the occurrence of age gradients in calcification and photosynthesis. J Exp Bot 27:864-878

> Borowitzka MA, Larkum AWD (1976b) Calcification in the green alga Halimeda. III. The sources of inorganic carbon for photosynthesis and calcification and a model of the mechanism of calcification. J Exp Bot 27:879-893

Borowitzka MA, Larkum AWD (1977) Calcification in the green alga Halimeda. I. An ultrastructure study of thallus development. J Phycol 13:6-16

Borowitzka MA, Larkum AWD (1987) Calcification in algae: mechanisms and the role of metabolism. CRC Crit Rev Plant Sci 6:1-45

> Campbell JE, Craft JD, Muehllehner N, Langdon C, Paul VJ (2014) Responses of calcifying algae (Halimeda spp.) to ocean acidification: implications for herbivores. Mar Ecol Prog Ser 514:43-56

Comeau S, Carpenter RC, Edmunds PJ (2013a) Coral reef calcifiers buffer their response to ocean acidification 
using both bicarbonate and carbonate. Proc R Soc B 280: 20122374

> Comeau S, Edmunds PJ, Spindel NB, Carpenter RC (2013b) The responses of eight coral reef calcifiers to increasing partial pressure of $\mathrm{CO}_{2}$ do not exhibit a tipping point. Limnol Oceanogr 58:388-398

de Beer D, Larkum AWD (2001) Photosynthesis and calcification in the calcifying algae Halimeda discoidea studied with microsensors. Plant Cell Environ 24:1209-1217

> Dickson AG, Millero FJ (1987) A comparison of the equilibrium constants for the dissociation of carbonic acid in seawater media. Deep Res Part A 34:1733-1743

Egilsdottir H, Noisette F, Noël LML, Olafsson J, Martin S (2013) Effects of $p \mathrm{CO}_{2}$ on physiology and skeletal mineralogy in a tidal pool coralline alga Corallina elongata. Mar Biol 160:2103-2112

El-Manawy IM, Shafik MA (2008) Morphological characterization of Halimeda (Lamouroux) from different biotopes on the Red Sea coral reefs of Egypt. Am-Euras J Agric Environ Sci 3:532-538

Fabricius KE, Langdon C, Uthicke S, Humphrey C and others (2011) Losers and winners in coral reefs acclimatized to elevated carbon dioxide concentrations. Nat Clim Change 1:165-169

Fabry VJ, Seibel BA, Feely RA, Orr JC (2008) Impacts of ocean acidification on marine fauna and ecosystem processes. ICES J Mar Sci 65:414-432

> Gao K, Zheng Y (2010) Combined effects of ocean acidification and solar UV radiation on photosynthesis, growth, pigmentation and calcification of the coralline alga Corallina sessilis (Rhodophyta). Glob Change Biol 16: 2388-2398

> Goreau TF (1963) Calcium carbonate deposition by coralline algae and corals in relation to their roles as reef-builders. Ann N Y Acad Sci 109:127-167

Hillis LW (1997) Coralgal reefs from a calcareous green alga perspective, and a first carbonate budget. In: Proc 8th Int Coral Reef Sym, Panama City, p 761-766

Hillis-Colinvaux LW (1980) Ecology and taxonomy of Halimeda: primary producer of coral reefs. Adv Mar Biol 17: $1-327$

Hillis-Colinvaux LW (1986) Deep water populations of Halimeda in the economy of an atoll. Bull Mar Sci 38:155-169

Hofmann L, Bischof K (2014) Ocean acidification effects on calcifying macroalgae. Aquat Biol 22:261-279

> Hofmann GE, Smith JE, Johnson KS, Send U and others (2011) High-frequency dynamics of ocean pH: a multiecosystem comparison. PLoS ONE 6:e28983

Hofmann LC, Straub S, Bischof K (2012a) Competition between calcifying and noncalcifying temperate marine macroalgae under elevated $\mathrm{CO}_{2}$ levels. Mar Ecol Prog Ser 464:89-105

> Hofmann LC, Yildiz G, Hanelt D, Bischof K (2012b) Physiological responses of the calcifying rhodophyte, Corallina officinalis (L.), to future $\mathrm{CO}_{2}$ levels. Mar Biol 159: 783-792

Hofmann LC, Heiden J, Bischof K, Teichberg M (2014) Nutrient availability affects the response of the calcifying chlorophyte Halimeda opuntia (L.) J.V. Lamouroux to low pH. Planta 239:231-242

> Holbrook GP, Beer S, Spencer WE, Reiskind JB, Davis JS, Bowes G (1988) Photosynthesis in marine macroalgae: evidence for carbon limitation. Can J Bot 66:577-582

IPCC (Intergovernmental Panel on Climate Change) (2013) Climate change 2013: The physical science basis. Contri- bution of Working Group I to the Fifth Assessment Report of the Intergovernmental Panel on Climate Change. Cambridge University Press, Cambridge

Jassby AD, Platt T (1976) Mathematical formulation of the relationship between photosynthesis and light for phytoplankton. Limnol Oceanogr 21:540-547

Jensen PR, Gibson RA, Littler MM, Littler DS (1985) Photosynthesis and calcification in four deep-water Halimeda species (Chlorophyceae, Caulerpales). Deep-Sea Res Part A 32:451-464

Johnson MD, Price NN, Smith JE (2014) Contrasting effects of ocean acidification on tropical fleshy and calcareous algae. PeerJ 2:e411

Jokiel PL, Maragos JE, Franzisket L (1978) Coral growth: buoyant weight technique. In: Stoddary DR, Johannes $\mathrm{RE}$ (eds) Coral reefs: research methods. UNESCO Monogr Oceanogr Methodology, p 529-541

Kangwe J, Semesi IS, Beer S, Mtolera M, Björk M (2012) Carbonate production by calcareous algae in a seagrassdominated system: the example of Chwaka Bay. In: de la Torre-Castro M, Lyimo TJ (eds) People, nature and research in Chwaka Bay, Zanzibar, Tanzania. WIOMSA, Zanzibar Town, p 143-156

> Koch M, Bowes G, Ross C, Zhang XH (2013) Climate change and ocean acidification effects on seagrasses and marine macroalgae. Glob Chang Biol 19:103-132

> Larkum AWD, Salih A, Kühl M (2011) Rapid mass movement of chloroplasts during segment formation of the calcifying siphonalean green alga, Halimeda macroloba. PLoS ONE 6:e20841

Littler MM, Littler DS, Lapointe BE (1988) A comparison of nutrient- and light-limited photosynthesis in psammophytic versus epilithic forms of Halimeda (Caulerpales, Halimedaceae) from the Bahamas. Coral Reefs 6: 219-225

Littler DS, Littler MM, Bucher KE, Norris JN (1989) Marine plants of the Caribbean: a field guide from Florida to Brazil. Smithsonian Institution Press, Washington, DC

Lobo F de A, de Barros MP, Dalmagro HJ, Dalmolin ÂC and others (2013) Fitting net photosynthetic light-response curves with Microsoft Excel - a critical look at the models. Photosynthetica 51:445-456

Macintyre IG, Reid PR (1995) Crystal alteration in a living calcareous algae (Halimeda): implications for studies in skeletal diagenesis. J Sediment Res A65:143-153

Martin S, Cohu S, Vignot C, Zimmerman G, Gattuso JP (2013) One-year experiment on the physiological response of the Mediterranean crustose coralline alga, Lithophyllum cabiochae, to elevated $p \mathrm{CO}_{2}$ and temperature. Ecol Evol 3:676-693

Mehrbach C, Culberson CH, Hawley JE, Pytkowicz RM (1973) Measurement of apparent dissociation-constants of carbonic acid in seawater at atmospheric pressure. Limnol Oceanogr 18:897-901

Milliman JD (1974) Recent sedimentary carbonates, part I. Marine carbonates. Springer-Verlag, New York, NY

Multer HG, Clavijo I (1989) Halimeda investigations: progress and problems. 12th Caribbean Geological Conference, St. Croix, US Virgin Islands, p 117-127

- Noisette F, Egilsdottir H, Davoult D, Martin S (2013) Physiological responses of three temperate coralline algae from contrasting habitats to near-future ocean acidification. J Exp Mar Biol Ecol 448:179-187

Pierrot D, Lewis E, Wallace DWR (2006) MS Excel program developed for $\mathrm{CO}_{2}$ systems calculations: ORNL/CDIAC- 
105a. Carbon Dioxide Information Analysis Center, Oak Ridge National Laboratory, US Department of Energy, Oak Ridge, TN

Price NN, Hamilton SL, Tootell JS, Smith JE (2011) Speciesspecific consequences of ocean acidification for the calcareous tropical green algae Halimeda. Mar Ecol Prog Ser 440:67-78

Rees SA, Opdyke BN, Wilson PA, Henstock TJ (2007) Significance of Halimeda bioherms to the global carbonate budget based on a geological sediment budget for the Northern Great Barrier Reef, Australia. Coral Reefs 26: $177-188$

Reiskind JB, Bowes G (1991) The role of phosphoenolpyruvate carboxykinase in a marine macroalga with $\mathrm{C}_{4}$-like photosynthetic characteristics. Proc Natl Acad Sci USA 88:2883-2887

Reiskind JB, Seamon PT, Bowes G (1988) Alternative methods of photosynthetic carbon assimilation in marine macroalgae. Plant Physiol 87:686-692

Ries JB, Cohen AL, McCorkle DC (2009) Marine calcifiers exhibit mixed responses to $\mathrm{CO}_{2}$-induced ocean acidification. Geology 37:1131-1134

Robbins LL, Knorr PO, Hallock P (2009) Response of Halimeda to ocean acidification: field and laboratory evidence. Biogeosciences Discuss 6:4895-4918

Sabine CL, Key RM, Kozyr A, Feely RA and others (2005) Global Ocean Data Analysis Project: results and data. ORNL/CDIAC-145, NDP-083. Carbon Dioxide Information Analysis Center, Oak Ridge National Laboratory, US Department of Energy, Oak Ridge, TN

Semesi IS, Beer S, Björk M (2009) Seagrass photosynthesis controls rates of calcification and photosynthesis of calcareous macroalgae in a tropical seagrass meadow. Mar Ecol Prog Ser 382:41-47

Sinutok S, Hill R, Doblin MA, Wuhrer R, Ralph PJ (2011) Warmer more acidic conditions cause decreased productivity and calcification in subtropical coral reef sedimentdwelling calcifiers. Limnol Oceanogr 56:1200-1212

Sinutok S, Hill R, Doblin MA, Kühl M, Ralph PJ (2012) Microenvironmental changes support evidence of photosynthesis and calcification inhibition in Halimeda under

Editorial responsibility: Steven Lohrenz,

New Bedford, Massachusetts, USA ocean acidification and warming. Coral Reefs 31: 1201-1213

Stoddart DR (1969) Ecology and morphology of recent coral reefs. Biol Rev Camb Philos Soc 44:433-498

Taiz L, Zeiger E (2010) Plant physiology, 5th edn. Sinauer Association, Sunderland, MA

> Vogel N, Fabricius KE, Strahl J, Noonan SHC, Wild C, Uthicke S (2015a) Calcareous green alga Halimeda tolerates ocean acidification conditions at tropical carbon dioxide seeps. Limnol Oceanogr 60:263-275

Vogel N, Meyer FW, Wild C, Uthicke S (2015b) Decreased light availability can amplify negative impacts of ocean acidification on calcifying coral reef organisms. Mar Ecol Prog Ser 521:49-61

> Vroom PS, Smith CM, Coyer JA, Walters LJ, Hunter CL, Beach KS, Smith JE (2003) Field biology of Halimeda tuna (Bryopsidales, Chlorophyta) across a depth gradient: comparative growth, survivorship, recruitment, and reproduction. Hydrobiologia 501:149-166

Wilbur KM, Hillis Colinvaux L, Watabe N (1969) Electron microscope study of calcification in the alga Halimeda (order Siphonales). Phycologia 8:27-35

Wiman SK, McKendree WG (1975) Distribution of Halimeda plants and sediments on and around a patch reef near Old Rhodes Key, Florida. J Sediment Petrol 45:415-421

Wizemann A, Meyer FW, Westphal H (2014) A new model for the calcification of the green macro-alga Halimeda opuntia (Lamouroux). Coral Reefs 33:951-964

Wizemann A, Mann T, Klicpera A, Westphal H (2015a) Microstructural analyses of sedimentary Halimeda segments from the Spermonde Archipelago (SW Sulawesi, Indonesia): a new indicator for sediment transport in tropical reef islands? Facies 61:4

Wizemann A, Meyer FW, Hofmann LC, Wild C, Westphal H (2015b) Ocean acidification alters the calcareous microstructure of the green macro-alga Halimeda opuntia. Coral Reefs 34:941-954

> Yildiz G, Hofmann LC, Bischof K, Dere (2013) Ultraviolet radiation modulates the physiological responses of the calcified rhodophyte Corallina officinalis to elevated $\mathrm{CO}_{2}$. Bot Mar 56:161-168

Submitted: March 24, 2015; Accepted: December 19, 2015 Proofs received from author(s): January 31, 2016 